\title{
1 A multi-stable isotope framework to understand eutrophication in aquatic ecosystems
}

2 Daren C Gooddy $^{\mathrm{a}^{*}}$, Dan J Lapworth ${ }^{\mathrm{a}}$, Sarah A Bennett ${ }^{\mathrm{bd}}$, Tim H E Heaton ${ }^{\mathrm{b}}$, Peter J Williams ${ }^{\mathrm{a}}$ and Ben 3 WJ Surridge $\mathrm{c}$.

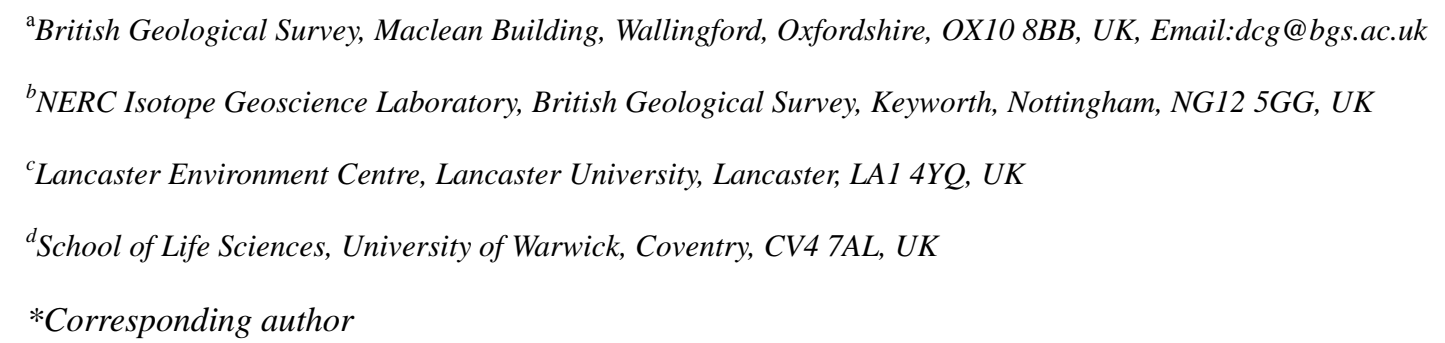

KEYWORDS: Eutrophication; nitrogen isotopes; phosphate oxygen isotopes; agriculture; waste water

\section{Abstract}

Eutrophication is a globally significant challenge facing aquatic ecosystems, associated with human induced enrichment of these ecosystems with nitrogen $(\mathrm{N})$ and phosphorus $(\mathrm{P})$. However, the limited availability of inherent labels for $\mathrm{P}$ and $\mathrm{N}$ has constrained understanding of the triggers for eutrophication in natural ecosystems and appropriate targeting of management responses. This paper proposes and evaluates a new multi-stable isotope framework that offers inherent labels to track biogeochemical reactions governing both $\mathrm{P}$ and $\mathrm{N}$ in natural ecosystems. The framework couples highly novel analysis of the oxygen isotope composition of phosphate $\left(\delta^{18} \mathrm{O}_{\mathrm{PO} 4}\right)$ with dual isotope analysis of oxygen and $\mathrm{N}$ within nitrate $\left(\delta^{15} \mathrm{~N}_{\mathrm{NO} 3}, \delta^{18} \mathrm{O}_{\mathrm{NO} 3}\right)$ and with stable $\mathrm{N}$ isotope analysis in ammonium $\left(\delta^{15} \mathrm{~N}_{\mathrm{NH} 4}\right)$. The River Beult in England is used as an exemplar system for initial evaluation of this framework. Our data demonstrate the potential to use stable isotope labels to track the input and downstream fate of nutrients from point sources, on the basis of isotopic differentiation for both $\mathrm{P}$ and $\mathrm{N}$ between river water and waste water treatment work effluent (mean difference $=+1.7 \%$ for $\delta^{18} \mathrm{O}_{\mathrm{PO} 4} ;+15.5 \%$ for $\delta^{15} \mathrm{~N}_{\mathrm{NH} 4}$ (under high flow); $+7.3 \%$ for $\delta^{18} \mathrm{O}_{\mathrm{NO} 3}$ and $+4.4 \%$ for $\delta^{15} \mathrm{~N}_{\mathrm{NO} 3}$ ). Stable isotope data reveal nutrient inputs to the river upstream of the waste water treatment works that are consistent with partially denitrified sewage or livestock sources of nitrate $\left(\delta^{15} \mathrm{~N}_{\mathrm{NO}}\right.$ range $=+11.5$ to $+13.1 \%$ ) and with agricultural sources of phosphate $\left(\delta^{18} \mathrm{O}_{\mathrm{PO} 4}\right.$ range $=+16.6$ to $\left.+19.0 \%\right)$. The 
importance of abiotic and metabolic processes for the in-river fate of $\mathrm{N}$ and $\mathrm{P}$ are also explored through the stable isotope framework. Microbial uptake of ammonium to meet metabolic demand for $\mathrm{N}$ is suggested by substantial enrichment of $\delta^{15} \mathrm{~N}_{\mathrm{NH} 4}$ (by $10.2 \%$ over a $100 \mathrm{~m}$ reach) under summer low flow conditions. Whilst the concentration of both nitrate and phosphate decreased substantially along the same reach, the stable isotope composition of these ions did not vary significantly, indicating that concentration changes are likely driven by abiotic processes of dilution or sorption. The in-river stable isotope composition and the concentration of $\mathrm{P}$ and $\mathrm{N}$ were also largely constant downstream of the waste water treatment works, indicating that effluent-derived nutrients were not strongly coupled to metabolism along this in-river transect. Combined with in-situ and laboratory hydrochemical data, we believe that a multi-stable isotope framework presents a powerful approach for understanding and managing eutrophication in natural aquatic ecosystems.

\section{Introduction}

Perhaps the most significant challenge facing aquatic ecosystems globally is cultural eutrophication (Schindler, 2012), the process of ecosystem change triggered by human induced enrichment of ecosystems with phosphorus (P) and nitrogen (N). Given the adverse ecological, social and economic impacts associated with eutrophication (Dodds et al., 2009; Pretty et al., 2003), significant research efforts have been directed towards understanding the causes of this process and targeting mitigation strategies. In the context of aquatic ecosystems, two long-standing paradigms suggest that primary production is limited by an individual nutrient element which thereby represents the trigger for eutrophication. In freshwaters the focus has been on limitation by the availability of P (e.g. Likens, 1972; Schindler, 1977), whilst within estuarine and coastal marine ecosystems the focus has been on N limitation (e.g. Ryther and Dunstan, 1971; Howarth, 1988). However, these paradigms have been subject to growing debate, stimulated by evidence of $\mathrm{N}$ limitation in freshwaters (e.g. Mischler et al., 2014; James et al., 2003), N/P co-limitation in freshwaters (e.g. Xu et al., 2010; Conley et al., 2009), or P limitation in marine/estuarine waters (e.g. Blomqvist et al, 2004). 
This debate reflects uncertainty regarding a number of the fundamental questions that surround eutrophication and appropriate responses to eutrophication (Smith and Schindler, 2009). An important source of this uncertainty is reliance on bioassays and mesocosms as the experimental basis for understanding nutrient limitation and eutrophication in aquatic ecosystems. These experimental approaches may not accurately reflect the large-scale, long-term processes that govern eutrophication in natural ecosystems, resulting in a bias towards identification of proximate rather than ultimate limiting nutrients (Vitousek et al., 2010) and data that do not scale successfully to natural ecosystems (Schindler, 2012). Past reliance on bioassays and mesocosms partly reflects the lack of inherent tracers that can be used to understand the sources and the reaction pathways which control $\mathrm{P}$ and $\mathrm{N}$ biogeochemistry in natural ecosystems (Karl, 2000). In this paper, we propose and evaluate a new multi-stable isotope framework that offers inherent tracers for $\mathrm{N}$ and $\mathrm{P}$ within aquatic ecosystems. Whilst multi-stable isotope approaches are increasingly used in other research fields, for example employing the stable isotopes of nitrate and sulphate in combination (e.g. Mayer, 2005; Kaown et al., 2009; Urresti-Estalaa et al., 2015) or combining stable isotope analyses in boron and nitrate (e.g. Briand et al., 2013), similar frameworks are yet to be developed in the context of $\mathrm{P}$ and $\mathrm{N}$ biogeochemistry within aquatic ecosystems.

Dual-isotope approaches for nitrate $\left(\delta^{15} \mathrm{~N}_{\mathrm{NO} 3}\right.$ and $\left.\delta^{18} \mathrm{O}_{\mathrm{NO} 3}\right)$ and stable ammonium isotope analyses $\left(\delta^{15} \mathrm{~N}_{\mathrm{NH} 4}\right)$ have been used to understand sources and reaction mechanisms for these ions in both groundwater and surface water (e.g. Böttcher et al., 1990; Böhlke and Denver 1995; Wassenaar 1995; Kendall 1998; Silva et al., 2000; Heaton et al., 2012; Gooddy et al., 2014). Biogeochemical cycling of $\mathrm{P}$ in aquatic ecosystems has previously been examined using the radioactive isotopes ${ }^{32} \mathrm{P}$ and ${ }^{33} \mathrm{P}(\mathrm{e} . \mathrm{g}$. Benitez-Nelson, 2000; Benitez-Nelson and Karl, 2002). However, the use of radioisotopes is constrained by short isotope half-lives, perturbation of experimental systems associated with labelling, or the use of incubations which omit irregular events in natural ecosystems, such as seasonal algal blooms (Levine et al., 1986; Thingstad et al., 1993; Benitez-Nelson, 2000). Stable isotope analyses cannot be conducted on the $\mathrm{P}$ atom in $\mathrm{P}$-containing compounds, because ${ }^{31} \mathrm{P}$ is the only stable $\mathrm{P}$ isotope. However, because $\mathrm{P}$ is often bound strongly to oxygen $(\mathrm{O})$ in the dissolved inorganic 
phosphate ion (Blake et al., 1997), hereafter $\mathrm{P}_{\mathrm{i}}$, attention has recently focussed on whether the stable isotope composition of $\mathrm{O}$ in $\mathrm{P}_{\mathrm{i}}\left(\delta^{18} \mathrm{O}_{\mathrm{PO} 4}\right)$ can provide new insights into sources and biogeochemical cycling of P in the environment (e.g. Young et al., 2009; Tamburini et al., 2014; Gooddy et al., 2015). The basis to the use of $\delta^{18} \mathrm{O}_{\mathrm{PO} 4}$ in aquatic ecosystems has recently been reviewed by Davies et al. (2014). Briefly, because the P-O bonds in $\mathrm{P}_{\mathrm{i}}$ are resistant to inorganic hydrolysis under typical temperature and pressure conditions in the Earth's surface water and groundwater ecosystems (O'Neil et al., 2003), negligible $\mathrm{O}$ isotope exchange occurs between $\mathrm{P}_{\mathrm{i}}$ and water within these ecosystems without biological mediation (Tudge, 1960; Blake et al., 1997). Under such abiotic conditions, $\delta^{18} \mathrm{O}_{\mathrm{PO} 4}$ may therefore reflect the isotope composition of P sources to an ecosystem. In contrast, enzymecatalysed reactions cleave $\mathrm{P}-\mathrm{O}$ bonds leading to fractionation between the isotopes of $\mathrm{O}$ in $\mathrm{P}_{\mathrm{i}}$ and $\mathrm{O}$ in a surrounding fluid, either within a cell or within the extracellular environment (Blake et al., 2005). Intracellular metabolism of P involving the inorganic pyrophosphatase enzyme results in rapid, temperature-dependent equilibrium fractionation between $\mathrm{O}$ in $\mathrm{P}_{\mathrm{i}}$ and $\mathrm{O}$ within the intracellular fluid, the latter is expected to be identical in O-isotope composition to water-O in the extracellular environment. Given sufficient intracellular-extracellular exchange of $\mathrm{P}$ to maintain non-lethal intracellular P concentrations, a temperature-dependent equilibrium will be established between $\delta^{18} \mathrm{O}_{\mathrm{PO} 4}$ and water-O in the extracellular environment. The equilibrium oxygen isotope fractionation between dissolved inorganic phosphate and water $\left(\alpha_{\mathrm{PO} 4-\mathrm{H} 2 \mathrm{O}}\right)$ at surface temperatures has recently been determined (Chang and Blake, 2015), using laboratory solutions catalyzed by the inorganic pyrophosphatase enzyme. These authors derived the equation:

$10^{3} \ln \alpha_{P O 4-H 2 O}=14.43 \times\left(10^{3} / T\right)-26.54$

where $\mathrm{T}$ is in degrees Kelvin. Since:

$$
\alpha_{P O 4-H 2 O}=\left(\delta^{18} O_{P O 4}+1000\right) /\left(\delta^{18} O_{H 2 O}+1000\right)
$$


by combining 1 and 2 above, expected equilibrium $\delta^{18} \mathrm{O}_{\mathrm{PO} 4}$ values may be calculated from:

$\delta^{18} O_{P O 4}=\left(\delta^{18} O_{H 2 O}+1000\right) \times e^{\left[14.43 \times\left(10^{3} / T\right)-26.54\right] / 1000}-1000$

However, only limited research has explored the use of $\delta^{18} \mathrm{O}_{\mathrm{PO} 4}$ in aquatic ecosystems, particularly within freshwater ecosystems. We are not aware of any research to date that has evaluated whether a multi-stable isotope approach has the potential to provide new insights into the controls on $\mathrm{P}$ and $\mathrm{N}$ biogeochemistry within natural ecosystems. Therefore, the objectives of our research were to: i) develop and apply a multi-stable isotope approach for $\mathrm{N}$ and $\mathrm{P}$ in freshwater ecosystems; and ii) evaluate the insights into the sources and reaction mechanisms controlling $\mathrm{P}$ and $\mathrm{N}$ biogeochemistry in freshwater ecosystems that can be provided through a multi-stable isotope approach.

\section{Materials and methods}

\subsection{Study area}

The River Beult which rises near Ashford in Kent, UK was used as an exemplar system to evaluate the multi-stable isotope framework. The Beult is the largest tributary of the River Medway and the only riverine Site of Special Scientific Interest (SSSI) in the county. Landuse within the Beult catchment is predominantly rural, with scattered settlements and an urban land coverage of $<1 \%$ of the total catchment area. The catchment is predominantly underlain by a thick clay formation (Weald Clay), largely excluding exchange between groundwater and river water. However, there is evidence that some groundwater discharge to surface waters may occur in the catchment, either where small areas of limestone outcrop or where the Weald Clay is discontinuous (Lapworth et al., 2009). Elevated concentrations of $\mathrm{P}$ are found widely within the catchment. For example in a survey conducted in $2008,75 \%$ of surface waters were found to exceed $100 \mu \mathrm{g} \mathrm{PO}_{4}-\mathrm{P} / \mathrm{L}$ (Lapworth et al., 2013). Elevated P concentrations place the SSSI in an "unfavourable condition" and exceed target water quality standards under the European Water Framework Directive (WFD, 2000). Elevated 
nitrate $\left(\mathrm{NO}_{3}\right)$ concentrations are also of concern, with many sites exceeding $30 \mathrm{mg} \mathrm{NO} / \mathrm{L}$ and therefore exceeding the surface water drinking directive limit of $25 \mathrm{mg} \mathrm{NO} / \mathrm{L}$ (Council Directive 75/440/EEC) and the mean annual concentration for the European Environment Agency's river basin district (RBD) classification (Class 5 for the study RBD). Given the predominant landuse within the catchment, agricultural sources coupled with effluent from rural waste water treatment works (WwTWs) are hypothesised to dominate $\mathrm{N}$ and $\mathrm{P}$ loads delivered to surface waters in the Beult catchment (Lapworth et al. 2013). However, the roles of these nutrient sources in controlling productivity and eutrophication risk in the catchment remain uncertain, as they do within many aquatic ecosystems globally.

\subsection{Sites and sampling}

A c. $200 \mathrm{~m}$ reach along the River Beult to the south east of the town of Sutton Valence was sampled during this research (Fig. 1). A total of seven sampling sites (SV1-SV7) were established along an inriver transect that ran both upstream and downstream of Sutton Valence WwTW (Table 1). Samples were collected from these sites twice in a six month period, to provide a seasonal contrast between low flow (September 2013) and high flow (January 2014) conditions. River water samples were collected from the centre of the flowing water course at each site using a submersible pump, ensuring that the inlet of the pump did not disturb river bed sediments during sampling. On-site parameters (dissolved oxygen (DO), $\mathrm{pH}$, temperature and specific electrical conductance (SEC)) were measured and, where appropriate, were allowed to stabilise prior to sampling. $\mathrm{DO}, \mathrm{SEC}$ and $\mathrm{pH}$ were measured in a flow-through cell to obtain representative field values. Samples for analysis of chloride, N species, soluble reactive P (SRP) and total dissolved P (TDP) were $0.45 \mu \mathrm{m}$ filtered in the field and collected in $30 \mathrm{~mL}$ plastic bottles. Samples for total P (TP) were not filtered and also collected in 30 $\mathrm{mL}$ plastic bottles. All samples for isotope analysis were also filtered in the field at $0.45 \mu \mathrm{m}$ using high capacity filters. Samples for $\delta^{15} \mathrm{~N}_{\mathrm{NO} 3}, \delta^{15} \mathrm{~N}_{\mathrm{NH} 4}$ and $\delta^{18} \mathrm{O}_{\mathrm{NO} 3}$ determination were filtered into $1 \mathrm{~L}$ plastic bottles; the samples for $\delta^{15} \mathrm{~N}_{\mathrm{NH} 4}$ determination were acidified in the field with concentrated $\mathrm{HCl}$ to $\mathrm{pH}$ 2-4. Samples for $\delta^{18} \mathrm{O}_{\mathrm{PO} 4}$ determination were filtered into $10 \mathrm{~L}$ plastic bottles. Samples for 
water-oxygen isotope analysis $\left(\delta^{18} \mathrm{O}_{\mathrm{H} 2 \mathrm{O}}\right)$ were collected in $10 \mathrm{~mL}$ glass bottles with rubber sealing caps.

\section{[Fig. 1. Location of the Beult catchment in England, UK (a) and schematic map of sample}

\section{locations along a section of the river (b)]}

\subsection{Hydrochemical analyses}

Soluble reactive $\mathrm{P}$ concentration, a measure of the inorganic monomeric and easily-hydrolysable $\mathrm{P}$ in a sample, was determined colorimetrically using the method of Murphy and Riley (1962) as modified by Neal et al. (2000). Total phosphorus concentration, the combination of TDP and particulate P concentrations, was determined by the method of Eisenreich et al. (1975) on unfiltered samples, whilst TDP concentration was determined using the same method but on filtered aliquots. Samples were analysed for the concentrations of $\mathrm{Cl}, \mathrm{NO}_{3}$ and nitrite $\left(\mathrm{NO}_{2}\right)$ using ion chromatography (IC), and for ammonium $\left(\mathrm{NH}_{4}\right)$ concentration by flow colorimetery.

\subsection{Sample preparation for isotope analysis}

Nitrate was separated from the sample matrix using anion exchange resins and prepared as silver nitrate using a method based on Chang et al. (1999). Ammonium was converted to ammonium sulphate on acidified quartz filter papers using a static ammonia diffusion technique (adapted from Sigman et al., 1997).

We developed and applied a new method to isolate $\mathrm{P}_{\mathrm{i}}$ from water samples and precipitate silver phosphate $\left(\mathrm{Ag}_{3} \mathrm{PO}_{4}\right)$ for isotope analysis, shown in Fig. 2 and described in detail in Lapworth et al. (2014). Samples were processed within $24 \mathrm{~h}$ of collection and were stored in the dark at $4{ }^{\circ} \mathrm{C}$ prior to processing. In brief, the majority of dissolved organic matter in a sample is first removed using an organic exchange resin and $\mathrm{P}_{\mathrm{i}}$ was then isolated from the remaining matrix using an anion exchange resin. Phosphate was eluted from the anion exchange resin and chromatographically separated from competing anions using $0.3 \mathrm{M} \mathrm{KCl}$. Eluted fractions containing phosphate are then processed using a modified McLaughlin et al. (2004) method to produce a final $\mathrm{Ag}_{3} \mathrm{PO}_{4}$ precipitate for $\delta^{18} \mathrm{O}_{\mathrm{PO} 4}$ analysis. 
Any residual organic matter remaining on the $\mathrm{Ag}_{3} \mathrm{PO}_{4}$ precipitate is removed by treatment with $15 \%$ hydrogen peroxide. We believe that the method shown in Fig.2 represents an advance over alternative sample preparation protocols (e.g. repeated $\mathrm{CePO}_{4}$ precipitation, $\mathrm{Li}$ et al. (2011)), in that it successfully prevents contamination of the final $\mathrm{Ag}_{3} \mathrm{PO}_{4}$ precipitate with organic compounds (see section 2.5 below) whilst also maintaining the final $\mathrm{Ag}_{3} \mathrm{PO}_{4}$ yield. The method reported in Fig. 2 is a multi-stage process (c. 14 days in total) and was carried out in batches of eight samples.

[Fig. 2. Schematic of the modified McLaughlin et al. (2004) protocol used to process water samples for $\delta^{18} \mathrm{O}_{\mathrm{PO} 4}$ analysis].

\subsection{Mass spectrometry}

The ratio ${ }^{15} \mathrm{~N} /{ }^{14} \mathrm{~N}$ in $\mathrm{NH}_{4}$ and $\mathrm{NO}_{3}$ was analysed by combustion in a Flash 1112 EA on-line to a Delta Plus XL mass spectrometer (ThermoFinnigan, Bremen, Germany), with $\delta^{15} \mathrm{~N}$ values versus atmospheric $\mathrm{N}_{2}$ calculated by comparison with standards IAEA N-1 and N-2 assuming these had $\delta^{15} \mathrm{~N}$ values of $+0.4 \%$ and $+20.3 \%$, respectively. Analytical precision ( $1 \mathrm{SD})$ was typically $<0.8 \%$, from repeat analysis of a sample. ${ }^{18} \mathrm{O} /{ }^{16} \mathrm{O}$ ratios of $\mathrm{NO}_{3}$ were analysed by thermal conversion to $\mathrm{CO}$ gas at $1400{ }^{\circ} \mathrm{C}$ in a TC-EA on-line to a Delta Plus XL mass spectrometer (ThermoFinnigan, Bremen, Germany), with $\delta^{18} \mathrm{O}$ values versus VSMOW calculated by comparison with standard IAEA- $\mathrm{NO}_{3}$ assuming it had a $\delta^{18} \mathrm{O}$ value of $+25.6 \%$. Analytical precision $(1 \mathrm{SD})$ was typically $<1.2 \%$.

${ }^{18} \mathrm{O} /{ }^{16} \mathrm{O}$ ratios of $\mathrm{Ag}_{3} \mathrm{PO}_{4}$ were analysed by thermal conversion to $\mathrm{CO}$ gas at $1400{ }^{\circ} \mathrm{C}$ in a TC-EA online to a Delta Plus XL mass spectrometer (ThermoFinnigan, Bremen, Germany).The $\delta^{18} \mathrm{O}_{\mathrm{PO} 4}$ value versus VSMOW was calculated by comparison with an internally run laboratory standard (Alfa Aesar silver phosphate, $99 \%$ ). In the absence of an international $\mathrm{Ag}_{3} \mathrm{PO}_{4}$ reference material, we derived the $\delta^{18} \mathrm{O}$ value of the laboratory standard by comparison with the $\mathrm{Ag}_{3} \mathrm{PO}_{4}$ standard 'B2207' (supplied by Elemental Microanalysis Ltd, Okehampton, England), which has a certified $\delta^{18} \mathrm{O}$ value of $+21.7 \%$ versus VSMOW. Any organic contamination of the $\mathrm{Ag}_{3} \mathrm{PO}_{4}$ produced using the protocol in Fig 2. was deemed to be negligible, based on $\mathrm{CO}$ yields of the $\mathrm{Ag}_{3} \mathrm{PO}_{4}$ samples always being within $\pm 10 \%$ of those of a laboratory $\mathrm{Ag}_{3} \mathrm{PO}_{4}$ standard, coupled with $\mathrm{Ag}_{3} \mathrm{PO}_{4}$ samples containing $<0.2 \%$ carbon (based 
on separate elemental analysis). Full replicates were processed through each stage of the extraction protocol reported in Fig. 2 on three occasions and on each occasion gave $\delta^{18} \mathrm{O}$ values within a range of $\pm 0.1 \%$ o (see Table 2). Analytical precision (1sd) was consistently $<0.2 \%$ and always less than $0.3 \%$ (Table 2). On this basis, we consider a difference in $\delta^{18} \mathrm{O}_{\mathrm{PO} 4}$ of $\geq 0.3 \%$ to be a reasonable indicator that two samples differ in isotopic composition for reasons other than analytical error.

\section{Results}

\subsection{Inorganic chemistry}

Table 1 reports on-site and laboratory hydrochemical data for low flow (September 2013) and high flow (January 2014) sampling events. Temperature data reflect the climatic difference between seasons, with average water temperature $>11^{\circ} \mathrm{C}$ warmer in September 2013 compared to January 2014. Dissolved oxygen concentration at sites SV1 and SV2 was elevated under high flow compared to low flow conditions, consistent with temperature-related control on oxygen solubility. However, DO concentration was particularly low at SV1 under low flow conditions, suggesting either an input of strongly anoxic water to the River Beult at this site, or that there was significant consumption of oxygen upstream of SV1. Sutton Valence WwTW (SV4) delivered effluent with elevated Cl concentrations to the River Beult under both high and low flow conditions. Consistent with the very low DO concentration, $\mathrm{Cl}$ concentrations at SV1 under low flow conditions were elevated compared to SV2 and compared to SV1 and SV2 under high flow conditions.

Concentrations of $\mathrm{NO}_{3}$ and SRP at river sampling sites were generally elevated under low flow compared to high flow conditions, likely driven by reduced dilution of point sources given lower discharge (Jarvie et al., 2006). Under low flow conditions, the concentrations of SRP and other P fractions were particularly high at SV1 and SV2, whilst the concentration of $\mathrm{NO}_{3}$ at $\mathrm{SV} 1$ was elevated compared to that at SV2. Ammonium and $\mathrm{NO}_{2}$ concentrations were generally low at all sampling sites during both sampling events, apart from SV1 and SV2 where high $\mathrm{NH}_{4}$ and $\mathrm{NO}_{2}$ concentrations were observed under low flow conditions and, to a much reduced extent and for $\mathrm{NH}_{4}$ only, under high flow conditions. Fig. 3 reports the relationship between $\mathrm{NO}_{3}$ and $\mathrm{Cl}$ concentration for all sites, under both 
low and high flow conditions $(\mathrm{r}=+1.00, \mathrm{p}<0.01$ and $\mathrm{r}=+0.929, \mathrm{p}<0.01$ respectively). For samples collected under low flow, a clustering of sites with high $\mathrm{NO}_{3}$ and high $\mathrm{Cl}$ concentrations is revealed, associated with the WwTW effluent (SV3 and SV4) and river sites downstream of the WwTW (SV5SV7). Sites SV1 and SV2 were characterised by relatively low $\mathrm{NO}_{3}$ and $\mathrm{Cl}$ concentrations during this sampling event. In contrast, three clusters of sites are revealed under high flow conditions, with SV5SV7 occupying an intermediate position between upstream sites (SV1 and SV2) and sites associated with the WwTW (SV3 and SV4). A similar clustering of sites and flow-dependency to the clustering is revealed in the relationships between SRP and $\mathrm{Cl}$ concentrations (Fig. 4), where $\mathrm{r}=-0.901, \mathrm{p}<0.01$ under low flow and $\mathrm{r}=+0.901, \mathrm{p}<0.01$ under high flow.

\section{[Fig. 3. Nitrate concentration against chloride concentration for low and high flow sampling} events.]

[Fig. 4. Soluble reactive phosphorus (SRP) concentration against chloride concentration for low and high flow sampling events (note change in scale of SRP concentration between low and flows).]

\subsection{Stable isotope data}

Table 2 summarises the stable isotope dataset from the River Beult. The overall range for $\delta^{15} \mathrm{~N}_{\mathrm{NO} 3}$ was +4.7 to $+13.1 \%$, whilst for $\delta^{18} \mathrm{O}_{\mathrm{NO} 3}$ the range was -0.8 to $+8.6 \%$. Both $\delta^{15} \mathrm{~N}_{\mathrm{NO} 3}$ and $\delta^{18} \mathrm{O}_{\mathrm{NO} 3}$ at $\mathrm{SV} 1$ and SV2 were enriched compared to all other sites and this pattern was consistent under both high and low flow conditions. Values of $\delta^{15} \mathrm{~N}_{\mathrm{NO} 3}$ for SV3 and SV4 were reduced, by 3.2-3.9 \%, during high flow compared to low flow conditions. Upstream river site SV2 was isotopically enriched compared to the final outflow from the WwTW (SV4), both for $\delta^{15} \mathrm{~N}_{\mathrm{NO} 3}$ (by $2.9 \%$ under low flow conditions and 5.9\%o under high flow conditions) and for $\delta^{18} \mathrm{O}_{\mathrm{NO}}$ (by 7.6\%o under low flow conditions and 7.2\%o under high flow conditions). Sites downstream of the WwTW (SV5-7) had $\delta^{15} \mathrm{~N}_{\mathrm{NO} 3}$ and $\delta^{18} \mathrm{O}_{\mathrm{NO} 3}$ values 
that were either dominated by those of the final effluent from the WwTW (low flow conditions), or were intermediate between values for SV4 and for SV1 and SV2 (high flow conditions). The relationship between $\delta^{15} \mathrm{~N}_{\mathrm{NO} 3}$ and $\mathrm{NO}_{3}$ concentration under low and high flow conditions is reported in Fig. 5 ( $r=-0.901, p<0.1$ and $r=-0.901, p<0.01$ respectively). A trend of decreasing $\delta^{15} \mathrm{~N}_{\mathrm{NO}}$ with increasing $\mathrm{NO}_{3}$ concentration was observed for both sampling events, with lowest $\mathrm{NO}_{3}$ concentrations and highest $\delta^{15} \mathrm{~N}_{\mathrm{NO} 3}$ values occurring upstream of the WwTW. Similar trends exist for $\delta^{18} \mathrm{O}_{\mathrm{NO} 3}$, although for brevity these data are not reported in a separate figure.

\section{[Fig. 5. Nitrate-nitrogen isotope composition ( $\left.\delta^{15} N_{N O 3}\right)$ composition against nitrate concentration} for high and low flow sampling events. Vertical bars show standard deviation on $\delta^{15} N_{\mathrm{NO} 3}$ (note change in scale for nitrate concentration between high and low flow events).]

A range of +10.0 to $+33.7 \%$ was observed for $\delta^{15} \mathrm{~N}_{\mathrm{NH} 4}$. Under low flow conditions, substantial enrichment of $\delta^{15} \mathrm{~N}_{\mathrm{NH} 4}$ was observed between SV1 and SV2, increasing by 12.2\%o over an in-river length of approximately $100 \mathrm{~m}$. Unfortunately, the concentration of $\mathrm{NH}_{4}$ at all other sites during this sampling event was too low to enable analysis of $\delta^{15} \mathrm{~N}_{\mathrm{NH} 4}$. A smaller enrichment in $\delta^{15} \mathrm{~N}_{\mathrm{NH} 4}(3.1 \%)$ was observed between SV1 and SV2 under high flow conditions. Under high flow conditions, $\delta^{15} \mathrm{~N}_{\mathrm{NH} 4}$ was enriched by $15.5 \%$ in the WwTW outflow (SV3) compared to upstream river site SV2, although insufficient $\delta^{15} \mathrm{~N}_{\mathrm{NH} 4}$ data were available to make this comparison under low flow conditions. At SV5SV7 under high flow conditions, $\delta^{15} \mathrm{~N}_{\mathrm{NH} 4}$ was intermediate between that of sites SV2 and SV3, whilst both the concentration of $\mathrm{NH}_{4}$ and $\delta^{15} \mathrm{~N}_{\mathrm{NH} 4}$ remained relatively constant in the river downstream of SV4 during this sampling event.

The stable isotope composition of $\mathrm{P}_{\mathrm{i}}$ varied between +15.1 and $+19.0 \%$ across the samples. Under low flow conditions, $\delta^{18} \mathrm{O}_{\mathrm{PO} 4}$ was relatively constant between SV1 and SV2. Although the absolute value of $\delta^{18} \mathrm{O}_{\mathrm{PO} 4}$ was constant between these sites, the departure from the theoretical equilibrium value changed from $+0.1 \%$ to $-1.5 \%$ as a result of shifts in water temperature and $\delta^{18} \mathrm{O}_{\mathrm{H} 2 \mathrm{O}}$ between SV1 and SV2 and therefore in the theoretical equilibrium of $\delta^{18} \mathrm{O}_{\mathrm{PO} 4}$ (Table 3). In contrast, under high flow conditions, the absolute value of $\delta^{18} \mathrm{O}_{\mathrm{PO} 4}$ increased by $0.4 \%$ from site SV1 to SV2, whilst the 
theoretical equilibrium value remained unchanged. Values of $\delta^{18} \mathrm{O}_{\mathrm{PO} 4}$ at SV2 were $1.2 \%$ and $2.2 \%$ enriched compared to the final effluent from the WwTW (SV4) under low and high flow conditions respectively. Under high flow conditions, $\delta^{18} \mathrm{O}_{\mathrm{PO} 4}$ at sites downstream of the WwTW outflow (SV5SV7) remained relatively constant at an average of $+17.6 \%$ \pm 0.1 . Under low flow conditions, there was some evidence of decreasing $\delta^{18} \mathrm{O}_{\mathrm{PO} 4}$ with distance downstream of the WwTW, although $\delta^{18} \mathrm{O}_{\mathrm{PO} 4}$ only decreased by $0.3 \%$ over the $35 \mathrm{~m}$ river reach and these samples remained between $-0.9 \%$ and $1.2 \%$ depleted compared to the theoretical equilibrium $\delta^{18} \mathrm{O}_{\mathrm{PO} 4}$ (Table 3). Marked differences in $\delta^{18} \mathrm{O}_{\mathrm{PO} 4}$ were observed across all sites between low and high flow conditions, with samples taken in January 2014 an average of 2\%o higher than samples taken in September 2013. The relationship between $\delta^{18} \mathrm{O}_{\mathrm{PO} 4}$ and SRP concentration under low and high flow conditions is shown in Fig. 6. Under low flow conditions, there was a trend of increasing $\delta^{18} \mathrm{O}_{\mathrm{PO} 4}$ with increasing SRP concentration $(\mathrm{r}=+0.90, \mathrm{p}<0.01)$, with the highest SRP concentration and $\delta^{18} \mathrm{O}_{\mathrm{PO} 4}$ occurring at sites SV1 and SV2. In contrast, under high flow conditions the trend was reversed $(\mathrm{r}=-0.811, \mathrm{p}<0.05-$ note lower confidence interval), with lowest SRP concentration and highest $\delta^{18} \mathrm{O}_{\mathrm{PO} 4}$ values occurring in samples from these same sites.

[Fig. 6. Stable phosphate oxygen composition ( $\left.\delta^{18} \mathrm{O}_{\mathrm{PO}}\right)$ composition against soluble reactive phosphorus (SRP) concentration for low and high flow sampling events. Vertical bars show standard deviation on $\delta^{18} \mathrm{O}_{\mathrm{PO} 4}$ (note change in scale for SRP concentration between low and high flow)].

\section{Discussion}

\subsection{Hydrochemical insights into controls on nutrient biogeochemistry}

The temporal and spatial variation in $\mathrm{N}$ and $\mathrm{P}$ concentrations reported in Table 1 may be interpreted through a mixing relationship between effluent from the WwTW and water in the River Beult upstream of the effluent discharge point. Under high flow conditions, WwTW effluent represents an 
end-member with elevated $\mathrm{NO}_{3}$ and SRP concentration and is diluted on entering the river. Dilution

314 produces downstream concentrations of $\mathrm{NO}_{3}$ and SRP in the River Beult that are intermediate

315 between the composition of the two end-members (Figs 3 and 4). Under low flow conditions, this

316 mixing pattern is repeated for $\mathrm{NO}_{3}$ although with reduced dilution of the WwTW effluent. However,

317 for both SRP and $\mathrm{NH}_{4}$ under low flow conditions, the final WwTW effluent effectively dilutes enriched upstream river water, to such an extent that downstream river concentrations of $\mathrm{NH}_{4}$ and SRP predominantly reflect effluent quality (Jarvie et al., 2010; Macdonald et al., 1995). Dissolved oxygen, $\mathrm{Cl}, \mathrm{NO}_{3}, \mathrm{NH}_{4}$ and $\mathrm{P}$ concentration data suggest a particular source of nutrient-enriched water influenced SV1 under low flow conditions, although these hydrochemical parameters suggest that the impact of this water source appeared to be absent, or at least significantly reduced, under high flow conditions.

Whilst the existence of the effluent and upstream end members, alongside flow-dependent variation in the mixing relationship between these end-members, is revealed by on-site and laboratory hydrochemical data, these data do not offer direct insights into two key questions related to understanding of the eutrophication process in aquatic ecosystems. Firstly, whilst the WwTW effluent appears to be an important source of $\mathrm{N}$ and $\mathrm{P}$ to the River Beult, the source of other nutrient inputs to the river remain uncertain, particularly at SV1 and SV2 under low flow conditions. This reflects the broader challenge of identifying the original source of nutrients, alongside the relative importance of different sources, in aquatic ecosystems (Jarvie et al., 2006). Secondly, concentration data alone do not provide direct insight into the biogeochemical mechanisms that govern the fate of nutrient elements during downstream transport within river ecosystems. Whilst indirect methods of source assessment have been developed, including the use of boron as a chemically conservative marker for WwTW effluent input to rivers (e.g. Neal et al., 2000) and microbial source tracking to identify human versus agricultural sources of faecal contamination (e.g. Scott et al., 2002), these methods do not offer an inherent label for either $\mathrm{P}$ or $\mathrm{N}$. As a result, they lack a direct and specific means of tracing in-river transformations of these nutrients. For example, both upstream and downstream of the WwTW, concentration changes may be driven by physical mixing of water sources, by abiotic 
geochemical mechanisms, or by metabolic processes. Discriminating between these individual processes is important if effective responses to eutrophication in aquatic ecosystems are to be developed. For example, understanding whether nutrients derived from WwTWs are strongly coupled to in-river metabolism is critical if capital and operating expenditure on nutrient removal technology at WwTWs is to be prioritised. Therefore, the extent to which a multi-stable isotope approach can provide insight into the key questions of source and in-river fate of nutrient elements is considered below.

\subsection{Differentiating sources of $P$ and $N$ on the basis of stable isotope composition}

Stable isotope data can provide insight into the original sources of $\mathrm{N}$ and $\mathrm{P}$ that contribute to aquatic ecosystems. Stable isotope analyses indicate that $\delta^{15} \mathrm{~N}_{\mathrm{NO}}$ at $\mathrm{SV} 1$ is enriched compared to the typical composition of $\mathrm{NO}_{3}$ derived from nitrification of $\mathrm{NH}_{4}$ within soils (Kendall, 1998; Heaton et al., 2012). Instead, the $\delta^{15} \mathrm{~N}_{\mathrm{NO} 3}$ composition is similar to that reported for $\mathrm{NO}_{3}$ derived from sewage or from livestock slurry or manure which has undergone partial denitrification, resulting in $\delta^{15} \mathrm{~N}_{\mathrm{NO}}$ between +10 and $+14 \%$ (Anisfield et al., 2007; Kendall et al., 2007). Denitrification of these sources of $\mathrm{N}$ upstream of SV1 may have been responsible for the $\delta^{15} \mathrm{~N}_{\mathrm{NO} 3}$ composition at this site. However, whilst the dual isotopes of $\delta^{15} \mathrm{~N}_{\mathrm{NO} 3}$ and $\delta^{18} \mathrm{O}_{\mathrm{NO} 3}$ provide a powerful basis for differentiating atmospheric and inorganic fertiliser sources of $\mathrm{NO}_{3}$ from each other, and from livestock or sewage sources, this dual isotope approach cannot distinguish between sewage and livestock sources, which requires the use of additional source markers such as boron isotopes (e.g. Briand et al., 2013). Enriched $\delta^{15} \mathrm{~N}_{\mathrm{NH} 4}$ at SV1 (>10\%) is also consistent with a livestock manure or slurry source that may have become isotopically enriched following volatilisation of ammonia (e.g. Widory et al., 2004). Although the existing global dataset remains relatively small, $\delta^{18} \mathrm{O}_{\mathrm{PO} 4}$ at $\mathrm{SV} 1$ is broadly consistent with the stable isotope composition of $\mathrm{P}$ derived from inorganic fertiliser or livestock excreta, sources that are characterised by $\delta^{18} \mathrm{O}_{\mathrm{PO} 4}$ between approximately +16 and $+20 \%$ (see Davies et al., 2014). 
Under low flow conditions, $\mathrm{Cl}, \mathrm{DO}, \mathrm{NO}_{3}, \mathrm{NH}_{4}$ and SRP concentrations are consistent with isotopic evidence for a distinct source of N and P that influences the River Beult at SV1, likely associated with agricultural activity or unsewered households in the upstream catchment. Under high flow conditions, significant changes in these hydrochemical parameters were observed at SV1, although it is not clear whether these changes in concentration are consistent with alternative sources of $\mathrm{N}$ and $\mathrm{P}$ influencing the river under high flow compared to low flow conditions. However, stable isotope data indicate that SV1 was dominated by similar sources of $\mathrm{N}$ and $\mathrm{P}$ under both low and high flow conditions, despite substantial changes in nutrient concentration between the two sampling events. Enrichment of $\delta^{15} \mathrm{~N}_{\mathrm{NO}}$ and $\delta^{18} \mathrm{O}_{\mathrm{NO} 3}$, depletion of $\delta^{15} \mathrm{~N}_{\mathrm{NH} 4}$ and enrichment of $\delta^{18} \mathrm{O}_{\mathrm{PO} 4}$ is observed at SV1 compared to downstream river sites and compared to the effluent from the WwTW, under both high and low flow conditions. This, coupled with relatively constant $\delta^{15} \mathrm{~N}_{\mathrm{NO} 3}, \delta^{18} \mathrm{O}_{\mathrm{NO} 3}$, and $\delta^{15} \mathrm{~N}_{\mathrm{NH} 4}$ values at $\mathrm{SV} 1$ across both sampling events, suggests that a common nutrient source influenced SV1 in September 2013 and January 2014. The $1.9 \%$ shift in $\delta^{18} \mathrm{O}_{\mathrm{PO} 4}$ at SV1 between low and high flow sampling events could indicate changes in the dominant source of $\mathrm{P}$ to the River Beult across these events. However, $\delta^{18} \mathrm{O}_{\mathrm{PO} 4}$ was consistent with the theoretical equilibrium value on both occasions, suggesting the $1.9 \%$ shift resulted from changes in equilibrium fractionation driven by changes in water temperature and $\delta^{18} \mathrm{O}_{\mathrm{H} 2 \mathrm{O}}$ between sampling events, rather than a change in P source. Fig. 7 shows this effect for all samples, by considering theoretical equilibrium values for a range of water temperatures.

[Fig. 7. A comparison of $\delta^{18} \mathrm{O}_{\mathrm{PO} 4}$ and $\delta^{18} \mathrm{O}_{\mathrm{H} 2 \mathrm{O}}$ for samples collected in low flow (filled symbols) and high flow (open symbols). Vertical and horizontal hashed areas represent range of measured $\delta^{18} \mathrm{O}_{\mathrm{H} 2 \mathrm{O}}$ during low and high flows respectively. Diagonal dashed lines represent the $\delta^{18} \mathrm{O}_{\mathrm{PO} 4}$ equilibrium values for ambient water for the range of temperatures at low and high flows calculated using the equation of Chang and Blake (2015).] final effluent samples differed substantially from that in river water upstream of the WwTW. Differentiation of nutrient sources on the basis of their stable isotope composition is the fundamental pre-requisite for using subsequent isotope fractionation to trace metabolism of nutrients derived from 
individual sources during in-river transport. Whilst previous work has examined the stable isotope composition of $\mathrm{NO}_{3}$ and $\mathrm{NH}_{4}$ in river water and in final effluent samples from WwTWs (e.g. Sebilo et al. 2006; Hood et al., 2014), our research represents some of the first data to demonstrate differentiation between effluent and upstream river water samples in terms of $\delta^{18} \mathrm{O}_{\mathrm{PO} 4}$ (although see also Gruau et al., 2005; McLaughlin et al., 2006; Young et al., 2009) The 1.4\% shift in $\delta^{18} \mathrm{O}_{\mathrm{PO} 4}$ in WwTW effluent between low and high flow conditions may indicate differences in the composition of waste water arriving at the WwTW, water residence time, or extent of metabolism within the works, and emphasises the need for more intensive characterisation and explanation of variation in $\delta^{18} \mathrm{O}_{\mathrm{PO}}$ within sources of P, such as WwTW effluent (see also Gruau et al., 2005). At SV3 under both high and low flow conditions, $\delta^{18} \mathrm{O}_{\mathrm{PO} 4}$ remained $-1.1 \%$ from theoretical equilibrium. This observation suggests that $\mathrm{P}$ is in excess of metabolic requirements within the WwTW, and is consistent with either an isotopically depleted source of SRP entering the works and passing conservatively through the treatment processes, or with kinetic isotope fractionation during the hydrolysis of organic $\mathrm{P}$ compounds within the WwTW that shifts $\delta^{18} \mathrm{O}_{\mathrm{PO} 4}$ towards isotopically depleted values (Blake et al., 2005).

\subsection{Stable isotope evidence for the in-river fate of $N$ and $P$}

Under low flow conditions, the concentration of $\mathrm{NH}_{4}$ decreased by two orders of magnitude between SV1 and SV2, suggesting potential nitrification within the stream network. The decrease in the concentration of $\mathrm{NO}_{3}$ between these same sites could be interpreted as evidence for in-stream denitrification or biological uptake of $\mathrm{NO}_{3}$ occurring alongside nitrification. For example, stream bed sediments have been shown to be potentially important locations for denitrification in river ecosystems (e.g. Seitzinger, 1988). Coupling stable isotope data for $\mathrm{NH}_{4}$ and $\mathrm{NO}_{3}$ enables the roles of nitrification and denitrification to be explored. Substantial increases in $\delta^{15} \mathrm{~N}_{\mathrm{NH} 4}$ were observed between SV1 and SV2, consistent with nitrification and a kinetic isotope effect in which isotopically lighter $\mathrm{NH}_{4}$ ions are preferentially nitrified, resulting in isotopic enrichment of the remaining $\mathrm{NH}_{4}$ in 
418 the extracellular environment (Middelburg and Nieuwenhuize, 2001). However, $\delta^{15} \mathrm{~N}_{\mathrm{NO3}}$ did not

419 decrease consistently between SV1 and SV2 across both sampling events, as would be expected

420 following generation of $\mathrm{NO}_{3}$ through nitrification (Sebilo et al., 2006). In addition, substantial

421 decreases in $\mathrm{NO}_{3}$ concentration were observed between SV1 and SV2 under both high and low flow

422 conditions, which is not consistent with nitrification. Whilst denitrification or biological uptake of

$423 \mathrm{NO}_{3}$ may have been responsible for decreases in $\mathrm{NO}_{3}$ concentration, no clear evidence was observed

424 for enrichment in $\delta^{15} \mathrm{~N}_{\mathrm{NO} 3}$ and $\delta^{18} \mathrm{O}_{\mathrm{NO} 3}$ that would be expected if denitrification or biological uptake

425 were responsible for the decrease in $\mathrm{NO}_{3}$ concentration between SV1 and SV2 (Heaton et al., 2012).

426 Sebilo et al. (2003) demonstrated that denitrification in stream bed sediments was not associated with

427 a large fractionation of $\delta^{15} \mathrm{~N}_{\mathrm{NO} 3}$, because diffusion of $\mathrm{NO}_{3}$ from the water column into reduced

428 sediments is the rate-limiting, but non-fractionating, step for denitrification in these environments.

429 However, given the three-fold decrease in $\mathrm{NO}_{3}$ concentration between $\mathrm{SV} 1$ and $\mathrm{SV} 2$ under low flow

430 conditions, the fact that $\delta^{15} \mathrm{~N}_{\mathrm{NO} 3}$ actually decreased between these sites on the River Beult is not

431 consistent with denitrification exerting a significant control on the fate of $\mathrm{N}$. There does not appear to

432 be strong isotopic evidence for denitrification within this upstream reach of the river.

Instead, stable isotope data suggest $\mathrm{NH}_{4}$ uptake and incorporation into biomass may have been responsible for the decreases in $\mathrm{NH}_{4}$ concentration observed between SV1 and SV2. Biological uptake under eutrophic conditions is associated with a kinetic isotope effect in which isotopically lighter ions are preferentially taken up and incorporated into biomass, resulting in isotopic enrichment of the remaining extracellular $\mathrm{NH}_{4}$ (Cifuentes et al., 1989). Whilst ammonia volatilisation may also increase $\delta^{15} \mathrm{~N}_{\mathrm{NH} 4}$ in any remaining $\mathrm{NH}_{4}$, stream temperature and $\mathrm{pH}$ were relatively consistent between SV1 and SV2 during both sampling events, meaning that volatilisation is unlikely to have been responsible for the observed decrease in $\mathrm{NH}_{4}$ concentration between these sites.

441 The lack of any substantial change in $\delta^{15} \mathrm{~N}_{\mathrm{NO} 3}$ or $\delta^{18} \mathrm{O}_{\mathrm{NO} 3}$ between SV1 and SV2 suggests decreases in $442 \mathrm{NO}_{3}$ concentration were unlikely to be due to metabolism, but were instead caused by an abiotic mechanism. Given the low affinity of $\mathrm{NO}_{3}$ for sediment sorption sites, the decrease in $\mathrm{NO}_{3}$ concentration alongside relatively constant $\delta^{15} \mathrm{~N}_{\mathrm{NO} O}$ and $\delta^{18} \mathrm{O}_{\mathrm{NO} 3}$ suggests dilution may have been 
responsible for the decreases in $\mathrm{NO}_{3}$ concentration between SV1 and SV2. The existence of an additional input of water to the River Beult is also supported by an increase in $\delta^{18} \mathrm{O}_{\mathrm{H} 2 \mathrm{O}}$ between SV1 and SV2, although this was only observed under low flow conditions suggesting that groundwater discharge to the river may have been responsible for dilution of $\mathrm{NO}_{3}$ between these sites. However, $\delta^{18} \mathrm{O}_{\mathrm{H} 2 \mathrm{O}}$ at SV2 under low flow conditions was outside the isotopic range for groundwater in this area of the UK, which lies between +6 and $+7 \%$ (Darling et al. 2003). Instead, $\delta^{18} \mathrm{O}_{\mathrm{H} 2 \mathrm{O}}$ suggests a water source characterised by partially evaporated surface water influenced the river at SV2, likely from drainage systems associated with the farming activity between SV1 and SV2. Whilst dilution may also have contributed to the decrease in $\mathrm{NH}_{4}$ concentration between these sites under low flow conditions, our data indicate that changes in $\mathrm{NH}_{4}$ concentration were also associated with substantial increases in $\delta{ }^{15} \mathrm{~N}_{\mathrm{NH} 4}$. This is indicative of metabolic processes influencing the in-river fate of $\mathrm{NH}_{4}$ but not $\mathrm{NO}_{3}$, offering insights into differences in the in-river fate of these ions as governed by their role in meeting metabolic demand for $\mathrm{N}$.

In contrast to $\delta^{15} \mathrm{~N}_{\mathrm{NH} 4}$, the value of $\delta^{18} \mathrm{O}_{\mathrm{PO} 4}$ for $\mathrm{SV} 1$ and SV2 under low flow conditions did not change substantially, despite a decrease of almost $50 \%$ in the concentration of SRP between these two sites. Consistent with $\mathrm{NO}_{3}$, the lack of substantial changes in stable isotope composition, coupled with a substantial decrease in concentration, suggests that an abiotic rather than metabolic mechanism controlled the concentration of SRP in this upstream reach of the river. Whilst dilution may also have been responsible for the change in SRP concentration, adsorption of $\mathrm{P}_{\mathrm{i}}$ to stream bed sediments can be significant (Jarvie et al., 2012). Some research has suggested that the initial stages of some abiotic reactions, such as sorption, are associated with kinetic isotope effects in which isotopically lighter $\mathrm{P}_{\mathrm{i}}$ ions are preferentially removed from solution (e.g. Jaisi et al., 2010). However, we observed no evidence for this in $\delta^{18} \mathrm{O}_{\mathrm{PO} 4}$ data at SV1 and SV2 under low flow conditions. Further, whilst the absolute value of $\delta^{18} \mathrm{O}_{\mathrm{PO} 4}$ did not change between SV1 and SV2, the deviation from expected equilibrium $\delta^{18} \mathrm{O}_{\mathrm{PO} 4}$ changed from 0.1 to $-1.5 \%$ as a result of differences in water temperature and $\delta^{18} \mathrm{O}_{\mathrm{H} 2 \mathrm{O}}$ between SV1 and SV2 and therefore the theoretical equilibrium value of $\delta^{18} \mathrm{O}_{\mathrm{PO} 4}$. The 471 increased deviation between observed and equilibrium $\delta^{18} \mathrm{O}_{\mathrm{PO} 4}$ values suggests a lack of intracellular 
metabolism of SRP in this upstream reach of the River Beult. In turn, this is consistent with molar N:P

473 and $\delta^{15} \mathrm{~N}_{\mathrm{NH} 4}$ in this reach that suggest $\mathrm{N}$ (and specifically $\mathrm{NH}_{4}$ ) rather than $\mathrm{P}$ is likely to limit

474 metabolic activity. Under high flow conditions, SRP concentration and $\delta^{18} \mathrm{O}_{\mathrm{PO}}$ increased from SV1 to

$475 \mathrm{SV} 2$. These data indicate that either an external source of $\mathrm{P}$, enriched in $\delta^{18} \mathrm{O}_{\mathrm{PO} 4}$, entered the river

476 between SV1 and SV2, or that SRP was re-generated from organic P compounds with partial

477 inheritance of an isotopically enriched $\delta^{18} \mathrm{O}_{\mathrm{PO} 4}$ composition from the source organic $\mathrm{P}$ compound

478 (Blake et al., 1997; Colman et al., 2005). Molar N:P between SV1 and SV2 suggest an increased

479 probability of $\mathrm{P}$ limitation or N/P co-limitation, meaning that regeneration of SRP from organic $\mathrm{P}$

480 compounds between these sites may have been promoted.

481 Examination of stable isotope data from SV5-SV7 also enables the potential links between $\mathrm{N}$ and $\mathrm{P}$

482 from WwTW effluent and in-stream metabolism to be examined. This is only possible because of the

483 difference between the stable isotope composition of $\mathrm{N}$ and $\mathrm{P}$ in the effluent and in the river immediately upstream of the WwTW. With respect to $\delta^{18} \mathrm{O}_{\mathrm{PO} 4}$, strong coupling between effluentderived $\mathrm{P}$ and in-river metabolism would be expected to rapidly imprint an equilibrium fractionation on SRP downstream of the WwTW, due to extensive uptake of SRP-intracellular equilibrium fractionation-release of SRP (Blake et al., 2005). Given reduced molar N:P at SV5-SV7 under low flow compared to high flow conditions, these samples are most likely to reveal isotopic evidence for in-stream metabolism of SRP. However, $\delta^{18} \mathrm{O}_{\mathrm{PO} 4}$ remained approximately $1 \%$ away from the theoretical equilibrium along the $35 \mathrm{~m}$ transect downstream of the WwTW under low flow conditions, indicating little evidence for significant in-stream metabolism of effluent derived SRP in this reach. Under high flow conditions, molar N:P suggests increased potential for N limitation or N/P colimitation at SV5-SV7. Values of $\delta^{18} \mathrm{O}_{\mathrm{PO} 4}$ remained relatively constant across these sites and, on average, $0.6 \%$ away from the theoretical equilibrium. However, there was also little isotopic evidence for in-stream metabolism of $\mathrm{NO}_{3}$ between SV5-SV7 under either high or low flow conditions. It is likely that the constrained transect length and associated residence time provided only limited opportunity for intracellular cycling and release of SRP to imprint an equilibrium isotope fractionation on $\delta^{18} \mathrm{O}_{\mathrm{PO} 4}$, or for metabolic processes to generate fractionation in the stable isotope composition of 
either $\mathrm{NH}_{4}$ or $\mathrm{NO}_{3}$. Longer downstream transects should be considered in order to fully evaluate the potential links between WwTW-derived nutreints and in-stream metabolism within streams and rivers using stable isotope approaches.

\section{Conclusions}

In-situ and laboratory hydrochemical data collected from the River Beult indicate that flow-dependent changes in mixing between upstream river water and final effluent from a WwTW strongly influence downstream river nutrient concentrations. However, these hydrochemical data alone provide no insight into the original sources of nutrients that influence eutrophication risk within the river, nor into the biogeochemical processes that govern the downstream fate of these nutrients. Our research demonstrates how a multi-stable isotope framework can provide additional insights into such questions that are fundamental to understanding the eutrophication process within freshwater ecosystems.

Stable isotope data suggest that nutrient input to the upstream reaches of the River Beult is dominated by sewage or agricultural sources under both high and low flow conditions, despite substantial changes in nutrient concentration across these different flow conditions. Stable isotope data support the need for measures to reduce diffuse water pollution from agriculture in order to address nutrient enrichment and eutrophication risk in the upstream reaches of the River Beult. In-river changes in stable isotope composition suggest an important role for microbial uptake of $\mathrm{NH}_{4}$ to meet metabolic demands for $\mathrm{N}$, particularly under low flow conditions. These data suggest that measures which target reductions in $\mathrm{NH}_{4}$ concentration within the River Beult should be prioritised in order to drive changes in autotrophic production within upstream river reaches. In contrast, changes in the concentration of $\mathrm{NO}_{3}$ and $\mathrm{SRP}$, interpreted through the stable isotope data, indicate that abiotic mechanisms control the fate of these ions in the upstream reach. Stable isotope data also suggest that $\mathrm{N}$ and $\mathrm{P}$ derived from a WwTW are not strongly coupled to metabolism within the river immediately downstream of the effluent discharge point, confirming the importance of addressing upstream sources of these nutrients. 
525 However, further sampling along a more extensive downstream transect would be required to

526 determine the ultimate fate of WwTW-derived nutrients within rivers using changes in stable isotope

527 composition.

528 Three priorities for further research should be addressed in order to fully realise the potential of the

529 multi-stable isotope framework proposed here. Firstly, the degree to which individual sources of

530 nutrients can be reliably distinguished on the basis of their stable isotope composition requires further

531 evaluation, particularly for $\delta^{18} \mathrm{O}_{\mathrm{PO} 4}$. Secondly, stable isotope data at higher temporal frequency are

532 required in order to evaluate short-term changes in the isotope composition of sources, for example

533 diurnal changes in final effluent from smaller WwTWs with short residence times. Finally, more

534 extensive and higher-intensity spatial sampling is required to assess the in-river fate of nutrients

535 derived from a range of sources, on the basis of changes in stable isotope composition. It is hoped that

536 the initial evaluation of a multi-stable isotope framework for $\mathrm{P}$ and $\mathrm{N}$ reported in this paper will help

537 stimulate future research to address these challenges.

\section{Acknowledgements}

539 The authors thank Flo Kent (Environment Agency) for assisting access during the sampling 540 campaigns, Marianne Stuart (British Geological Survey) for helpful comments on the draft manuscript as well as the Associate Editor and two anonymous reviewers. This paper is published with the permission of the Executive Director, British Geological Survey (NERC).

\section{References}

Anisfeld SC, Barnes RT, Altabet, MA and Wu T. 2007. Isotopic apportionment of atmospheric and sewage nitrogen sources in two Connecticut rivers. Environmental Science and Technology 41, 6363-6369. 
Benitez-Nelson CR and Karl DM. 2002. Phosphorus cycling in the North Pacific Subtropical Gyre using cosmogenic ${ }^{32} \mathrm{P}$ and ${ }^{33} \mathrm{P}$. Limnology and Oceanography 47, 3, 762-770.

Benitez-Nelson CR. 2000. The biogeochemical cycling of phosphorus in marine systems. EarthScience Reviews 51, 1-4, 109-135.

Böhlke JK and Denver JM. 1995. Combined use of groundwater dating, chemical, and isotopic analyses to resolve the history and fate of nitrate contamination in two agricultural water sheds. Atlantic coastal plain, Maryland. Water Resources Research 31, 2319-2339.

Böttcher J, Strbel O, Voerkelius S and Schimidt HL 1990. Using isotope fractionation of nitratenitrogen and nitrate-oxygen for evaluation of microbial denitrification in a sandy aquifer. Journal of Hydrology 114, 413-424.

Blomqvist S, Gunnars A and Elmgren R. 2004. Why the limiting nutrient differs between temperate coastal seas and freshwater lakes: A matter of salt. Limnology and Oceanography 49, 6, 22362241.

Blake RE, O’Neil JR and Garcia GA. 1997. Oxygen isotope systematics of biologically mediated reactions of phosphate: 1. Microbial degradation of organophosphorus compounds. Geochimica et Cosmochimica Acta 61, 4411-4422.

Blake RE, O’Neil JR and Surkov AV. 2005. Biogeochemical cycling of phosphorus: Insights from oxygen isotope effects of phosphoenzymes. American Journal of Science 305, 6-8, 596-620.

Briand C, Plagnes V, Sebilo M, Louvat P, Chesnot T, Schneider M, Ribstein P and Marchet P. 2013. Combination of nitrate $(\mathrm{N}, \mathrm{O})$ and boron isotopic ratios with microbiological indicators for the determination of nitrate sources in karstic groundwater. Environmental Chemistry 10, 365.

Chang CCY, Langston J, Riggs M, Campbell DH, Silva SR and Kendall C. 1999. A method for nitrate collection for $\delta^{15} \mathrm{~N}$ and $\delta^{18} \mathrm{O}$ analysis from waters with low nitrate concentrations. Canadian Journal of Fisheries and Aquatic Science 56, 1856-1864. 
Chang SJ and Blake RE. 2015. Precise calibration of equilibrium oxygen isotope fractionations between dissolved phosphate and water from $3-37^{\circ} \mathrm{C}$. Geochimica et Cosmochimica Acta 150, 314-329.

Cifuentes LA, Fogel ML, Pennock JR and Sharp JH. 1989. Biogeochemical factors that influence the stable isotope ratio of dissolved ammonium in the Delaware Estuary. Geochimica et Cosmochimica Acta 53, 2713-2721.

Conley DJ, Paerl HW, Howarth RW, Boesch DF, Seitzinger SP, Havens KE, Lancelot C and Likens GE. 2009. Controlling eutrophication: Nitrogen and phosphorus. Science 323, 5917, 10141015 .

Colman AS, Blake RE, Karl DM, Fogel ML and Turekian KK. 2005. Marine phosphate oxygen isotopes and organic matter remineralization in the oceans. Proceedings of the National Academy of Science of the USA 102, 37, 13023-8.

Darling WG, Bath AH and Talbot JC. 2003. The O and H stable isotopic composition of fresh waters in the British Isles. 2. Surface waters and groundwater. Hydrology and Earth System Science 7, 2, 183-195.

Council Directive 75/440/EEC. 1975. Concerning the quality required of surface water intended for the abstraction of drinking water in the Member States. Official Journal of the European Communities L194, 18, 26-31.

Davies CL, Surridge BWJ and Gooddy DC. 2014. Phosphate oxygen isotopes within aquatic ecosystems: Global data synthesis and future research priorities. Science of the Total Environment 496, 563-575.

Dodds WK, Bouska WW, Eitzmann JL, Pilger TJ, Pitts JL, Riley AJ, Schloesser JT and Thornbrugh DJ. 2009. Eutrophication of U.S. Freshwaters: Analysis of Potential Economic Damages. Environmental Science and Technology, 2009, 43, 1, 12-19. 
Eisenreich SJ, Bannerman RT and Armstrong DE. 1975. A simplified phosphorus analytical technique. Environmental Letters, 9, 45-53.

Gooddy DC, Macdonald DMJ, Lapworth DJ, Bennett SA and Griffiths KJ. 2014. Nitrogen Sources, Transport and Processing in Peri-Urban Floodplains. Science of the Total Environment 494-

600 495, 28-38.

601

602

603

604

605

606

607

608

609

610

611

612

James C, Fisher LJ and Moss B. 2003. Nitrogen driven lakes: the Shropshire and Cheshire meres?

Jarvie HP, Neal C and Withers PJA. 2006. Sewage-effluent phosphorus: A greater risk to river eutrophication than agricultural phosphorus. Science of the Total Environment, 360, 246-253. 
Jarvie HP, Sharpley AN, Scott JT, Haggard BE, Bowes MJ and Massey LB. 2012. Within-river phosphorus retention: Accounting for a missing piece in the watershed phosphorus puzzle. Environmental Science and Technology 46, 13284-13292.

Jarvie HP, Withers PJA, Bowes MJ, Palmer-Felgate EJ, Harper DM, Wasiak K, Hodgkinson RA, Bates A, Stoate C, Neal M, Wickham HD, Harman SA and Armstrong LK. 2010. Streamwater phosphorus and nitrogen across a gradient in rural-agricultural land use intensity. Agriculture, Ecosystems and Environment 135, 238-252.

Kendall C. 1998 Tracing nitrogen sources and cycling in catchments. In: Isotope Tracers in Catchment Hydrology (Eds C. Kendall \& J.J. McDonnell), pp. 519-576. Elsevier, Amsterdam.

Kendall C, Elliott EM and Wankel SD. 2007. "Tracing anthropogenic inputs of nitrogen to ecosystems", Stable Isotopes in Ecology and Environmental Science, $2^{\text {nd }}$ edition (Michener R and Lajtha K Eds), Blackwell Publishing 375-449

Kaown D, Koh D-C, Mayer B and Lee K-K. 2009. Identification of nitrate and sulphate sources in groundwater using dual stable isotope approached for an agricultural area with different land use (Chuncheon, mid-eastern Korea). Agriculture, Ecosystems and Environment, 132, 223 231.

Karl DM. 2000. A new source of 'new' nitrogen in the sea. Trends in Microbiology 8, 7, 301-301.

Lapworth DJ, Gooddy DC, Allen D, Williams PJ, Heaton THE, Kent F and Penn R. 2009. Phosphate sources in the Beult catchment, Kent - a multi technique approach. British Geological Survey Internal Report IR/09/040.

Lapworth DJ, Gooddy DC, Kent F, Heaton THE, Cole SJ and Allen D. 2013. A combined geochemical and hydrological approach to understanding macronutrient sources. Journal of Hydrology 500, 226-242. 
Lapworth DJ, Surridge BJW, Williams PJ, Heaton THE and Gooddy DC. 2014. Method for analysis of phosphate ${ }^{18} \mathrm{O} /{ }^{16} \mathrm{O}$ ratios in waters with high C:P ratios. British Geological Survey Open Report OR/14/67.

Levine SN, Stainton MP and Schindler DW. 1986. A radiotracer study of phosphorus cycling in a eutrophic Canadian Shield lake, Lake 227, northwestern Ontario. Canadian Journal of Fish and Aquatic Sciences 43, 366-378

Li X, Wang Y, Stern J and Gu B. 2011. Isotopic evidence for the source and fate of phosphorus in Evergaldes wetland ecosystems. Applied Geochemistry 26, 688-695.

Likens GE (Ed). 1972. Nutrients and eutrophication. American Society for Limnology and Oceanography Special Symposium. 1.328 p

Macdoanld AM, Edwards AC, Pugh KB and Balls PW. 1995. Soluble nitrogen and phosphorus in the River Ythan system, U.K.: Annual and seasonal trends. Water Research 39, 837-846.

Mayer B. 2005. Assessing sources and transformartions of sulphate and nitrate in the hydrosphere using isotopic techniques. In: Aggarwal PK, Gat JR, Froelich FO (Eds.). Isotopes in the Water Cycle: Past, Present and Future of a Developing Science pp67-90. Springer, Dordrecht, Netherlands.

McLaughlin K, Silva S, Kendall C, Stuart-Williams H and Paytan A. 2004. A precise method for the analysis of $\delta^{18} \mathrm{O}$ of dissolved inorganic phosphate in seawater. Limnology and Oceanography Methods 2, 202-212.

McLaughlin K, Kendall C, Silva S, Young M and Paytan A. 2006. Phosphate oxygen isotope ratios as a tracer for sources and cycling of phosphate in North San Francisco Bay, California. Journal of Geophysical Research, Biogeosciences 111, G03003, doi: 10.1029/2005JG000079

Middelburg JJ and Nieuwenhuize J. 2001. Nitrogen isotope tracing of dissolved nitrogen behaviour in 
Mischler JA, Taylor PG, Townsend AR. 2014. Nitrogen Limitation of Pond Ecosystems on the Plains of Eastern Colorado. PLoS ONE 9, 5: e95757.

669

670

Murphy J and Riley JP. 1962. A modified single solution method for the determination of phosphate in natural waters. Analitica Chemica Acta 27, 31-36.

Neal C, Jarvie HP, Howarth SM, Whitehead PG, Williams RJ, Neal M, Harrow M and Wickham H. 2000. The water quality of the River Kennet: initial observations on a lowland chalk stream impacted by sewage inputs and phosphorus remediation. Science of the Total Environment $251 / 252,477-496$

O'Neil JR, Vennemann TW and Mckenzie WF. 2003. Effects of speciation on equilibrium fractionations and rates of oxygen isotope exchange between $\left(\mathrm{PO}_{4}\right)(\mathrm{aq})$ and $\mathrm{H}_{2} \mathrm{O}$. Geochimica et Cosmochimica Acta 67, 3135

Pretty JN, Mason CF, Nedwell DB, Hine RE, Leaf S and Dils R. 2003. Environmental Costs of Freshwater Eutrophication in England and Wales. Environmental Science and Technology 37, 2, 201-208

Ryther JH and Dunstan WM. 1971. Nitrogen, Phosphorus, and Eutrophication in the Coastal Marine Environment. Science 171, 3975, 1008-1013.

Scott T, Rose J, Jenkins T, Farrah S and Lukasik J. 2002. Microbial source tracking: current methodology and future directions. Applied Environmental Microbiology 68, 12, 5796-5803.

Sebilo M, Billen G, Grably M and Mariotti A. 2003. Isotopic composition of nitrate-nitrogen as a marker of riparian and benthic denitrification at the scale of the whole Seine River system. Biogeochemistry 63, 35-51.

Sebilo M, Billen G, Mayer B, Billiou D, Grably M, Garnier J and Mariotti A. 2006. Assessing 
Seitzinger SP. 1988. Denitrfication in freshwater and coastal marine ecosystems: Ecological and geochemical significance. Limnology and Oceanography 33, 702-724.

Schindler DW. 1977. Evolution of Phosphorus Limitation in Lakes. Science 195, 4275, 260-262.

Schindler DW. 2012. The dilemma of controlling cultural eutrophication of lakes. Proceedings of the Royal Society B 279, 1746, 4322-4333.

Scott TM, Rose JB, Jenkins TM, Farrah SR and Lukasik J. 2002. Microbial source tracking: Current methodology and future directions. Applied and Environmental Microbiology 68, 5796-5803.

Sigman DM, Altyabet MA, Michener R, McCorkle DC, Fry B, and Holmes RM. 1997. Natural abundance-level measurement of the nitrogen isotopic composition of oceanic nitrate: an adaption of the ammonia diffusion method. Marine Chemistry, 57, 227-242.

Silva SR, Kendall C, Wilkison DH, Ziegler AC, Chang CCY and Avanzino RJ. 2000. A new method for collection of nitrate from fresh water and the analysis of nitrogen and oxygen isotope ratios. Journal of Hydrology 228, 22-36.

Smith VH and Schindler DW. 2009. Eutrophication science: where do we go from here? Trends in Ecology and Evolution 24, 201-207.

Tamburini F, Pfahler V, Von Sperber C, Frossard E and Bernasconi S. 2014. Oxygen isotopes for unravelling phosphorus transformations in the soil-plant system: a review. Soil Science Society of America Journal 78, 38-46

Thingstad TF, Skjoldal EF and Bohne RA. 1993. Phosphorus cycling and algal-bacterial competition in Sandsfjord, western Norway. Marine Ecology Progress Series 99, 3, 239-259.

711 Tudge A P. 1960. A Method of Analysis of Oxygen Isotopes in Orthophosphate - Its Use in the 
Urresti-Estalaa B, Vadillo-Péreza I, Jiménez-Gavilána P, Solerb A, Sánchez-Garcíaa D and CarrascoCantosa F. 2015. Application of stable isotopes $\left(\delta^{34} \mathrm{~S}_{-} \mathrm{SO}_{4}, \delta^{18} \mathrm{O}-\mathrm{SO}_{4}, \delta^{15} \mathrm{~N}-\mathrm{NO}_{3}, \delta^{18} \mathrm{O}-\mathrm{NO}_{3}\right)$ to determine natural background and contamination sources in the Guadalhorce River Basin (southern Spain). Science of the Total Environment 506-507, 46-57.

Vitousek P, Porder S, Houlton BZ and Chadwick OA. 2010. Terrestrial phosphorus limitation: mechanisms, implications, and nitrogen-phosphorus interactions. Ecological Applications 20, $5-15$

Wassenaar LI. 1995. Evaluation of the origin and fate of nitrate in the Abbortsford Aquifer using the isotopes of ${ }^{15} \mathrm{~N}$ and ${ }^{18} \mathrm{O}$ in $\mathrm{NO}_{3}{ }^{-}$. Applied Geochemistry, 10, 391-405.

Water Framework Directive (WFD), Council of European Communities. 2000. Establishing a framework for community action in the field of water policy (WFD;2000/60/EC). Official Journal of The European Communities L327, 43, 1-72.

Widory D, Kloppmann W, Chery L, Bonnin J, Rochdi H and Guinamant, JL. 2004. Nitrate in groundwater: an isotopic multi-tracer approach. Journal of Contaminant Hydrology 72,165188

Xu H, Paerl HW, Qin B, Zhu G and Gao G. 2010. Nitrogen and phosphorus inputs control phytoplankton growth in eutrophic Lake Taihu, China. Limnology and Oceanography 55, $420-432$

Young MB, McLaughlin K, Kendal C, StringfellowW, Rollog M, Elsbury K, Donald E and Paytan A. 2009, Characterizing the oxygen isotopic composition of phosphate sources to aquatic ecosystems. Environmental Science and Technology 43, 14, 5190-5196. 
Table 1. On site parameters and concentration of selected nutrients and anions in the River Beult under low and high flow conditions.

\begin{tabular}{|c|c|c|c|c|c|c|c|c|c|c|c|c|}
\hline \multicolumn{2}{|l|}{ Site } & \multirow{2}{*}{$\begin{array}{l}\text { Temp. } \\
{ }^{\circ} \mathrm{C} \\
\end{array}$} & \multirow{2}{*}{$\begin{array}{c}\mathbf{p H} \\
- \\
\end{array}$} & \multirow{2}{*}{$\begin{array}{l}\text { DO } \\
\mathrm{mg} / \mathrm{L} \\
\end{array}$} & \multirow{2}{*}{$\begin{array}{l}\mathbf{C l} \\
\mathrm{mg} / \mathrm{L} \\
\end{array}$} & \multirow{2}{*}{$\begin{array}{l}\mathrm{NO}_{3} \\
\mathrm{mg} \mathrm{NO}_{3} / \mathrm{L} \\
\end{array}$} & \multirow{2}{*}{$\begin{array}{l}\mathbf{N O}_{2} \\
\mathrm{mg} \mathrm{NO}_{2} / \mathrm{L}\end{array}$} & \multirow{2}{*}{$\begin{array}{l}\mathbf{N H}_{4} \\
\mathrm{mg} \mathrm{NH}_{4} / \mathrm{L}\end{array}$} & \multirow{2}{*}{$\begin{array}{l}\text { SRP } \\
\mu g \mathrm{P} / \mathrm{L}\end{array}$} & \multirow{2}{*}{$\begin{array}{l}\text { TDP } \\
\mu g \text { P/L }\end{array}$} & \multirow{2}{*}{$\begin{array}{l}\text { TP } \\
\mu g \text { P/L }\end{array}$} & \multirow{2}{*}{$\begin{array}{l}\mathbf{N}: \mathbf{P} \\
\text { molar }\end{array}$} \\
\hline & & & & & & & & & & & & \\
\hline \multicolumn{13}{|c|}{ Low Flow (Sep 2013) } \\
\hline SV1 & DS Poultry and soft fruit farm & 21.0 & 7.80 & $<0.5$ & 60.1 & 33.4 & 3.11 & 34.0 & 2090 & 2135 & 2440 & 30 \\
\hline SV2 & 50 m ds of Livestock Farm & 17.2 & 7.77 & 3.2 & 38.8 & 10.6 & 0.251 & 0.324 & 1296 & 1322 & 1955 & 3.0 \\
\hline SV3 & WWTW outflow & 20.3 & 7.76 & 6.5 & 93.8 & 131 & 0.126 & 0.043 & 888 & 918 & 954 & 68 \\
\hline SV4 & Reed bed outflow & 18.6 & 7.54 & 5.5 & 93.3 & 130 & 0.064 & 0.008 & 948 & 942 & 952 & 68 \\
\hline SV5 & $5 \mathrm{~m}$ ds of outflow & 18.3 & 7.80 & 5.4 & 86.9 & 119 & 0.056 & 0.012 & 964 & 974 & 978 & 61 \\
\hline SV6 & $10 \mathrm{~m}$ ds of outflow & 18.4 & 7.62 & 5.5 & 92.8 & 126 & 0.063 & 0.010 & 956 & 938 & 1002 & 63 \\
\hline SV7 & 35 m ds of outflow & 18.8 & 7.97 & 7.5 & 91.3 & 123 & 0.024 & 0.028 & 948 & 956 & 1016 & 60 \\
\hline \multicolumn{13}{|c|}{ High Flow (Jan 2014) } \\
\hline SV1 & DS Poultry and soft fruit farm & 7.4 & 7.71 & 4.5 & 37.7 & 34.5 & $<0.005$ & 0.352 & 181 & 195 & 297 & 60 \\
\hline SV2 & $50 \mathrm{~m}$ ds of Livestock Farm & 7.1 & 7.85 & 10.1 & 32.7 & 23.8 & $<0.005$ & 0.332 & 301 & 322 & 512 & 24 \\
\hline SV3 & WWTW outflow & 9.6 & 7.60 & 7.9 & 84.2 & 75.1 & 0.232 & 0.105 & 1020 & 1096 & 1264 & 29 \\
\hline SV4 & Reed bed outflow & 9.8 & 7.20 & 7.4 & 86.1 & 72.1 & 0.014 & 0.025 & 1036 & 1060 & 1152 & 31 \\
\hline SV5 & $5 \mathrm{~m}$ ds of outflow & 7.3 & 7.57 & 4.1 & 47.9 & 37.1 & $<0.005$ & 0.123 & 516 & 552 & 706 & 27 \\
\hline SV6 & $10 \mathrm{~m}$ ds of outflow & 7.4 & 7.51 & 4.2 & 48.6 & 36.9 & 0.100 & 0.134 & 524 & 559 & 742 & 25 \\
\hline SV7 & $35 \mathrm{~m}$ ds of outflow & 6.8 & 7.41 & 4.2 & 46.8 & 35.6 & 0.457 & 0.142 & 524 & 598 & 768 & 23 \\
\hline
\end{tabular}


Table 2. Stable isotope data for nitrate, ammonium, phosphate and water sampled under high and low flow conditions on the River Beult. Average value reported for duplicates ( ${ }^{\mathrm{a}} 15.1$ and 15.02; ${ }^{b} 16.6$ and $16.65{ }^{c} 16.2$ and 16.1). * indicates insufficient sample to calculate standard deviation.

\begin{tabular}{|c|c|c|c|c|c|c|c|c|c|}
\hline \multirow[t]{2}{*}{ Site } & \multicolumn{2}{|c|}{$\delta^{15} \mathrm{~N}-\mathrm{NO}_{3}$} & \multicolumn{2}{|c|}{$\delta^{18} \mathrm{O}-\mathrm{NO}_{3}$} & \multicolumn{2}{|c|}{$\delta^{15} \mathrm{~N}-\mathrm{NH}_{4}$} & \multirow[t]{2}{*}{$\mathrm{H}_{2} \mathrm{O}-\delta^{18} \mathrm{O}$} & \multicolumn{2}{|c|}{$\delta^{18} \mathrm{O}-\mathrm{PO} 4$} \\
\hline & $\%$ & \pm & $\%$ & \pm & $\%$ & \pm & & $\%$ & \pm \\
\hline \multicolumn{10}{|c|}{ Low Flow (Sep 2013) } \\
\hline SV1 & 13.1 & 0.3 & 7.8 & 0.5 & 10.0 & 0.1 & -6.08 & 16.7 & 0.2 \\
\hline SV2 & 12.2 & 0.4 & 8.6 & 0.4 & 20.2 & 0.7 & -5.22 & $16.6^{\mathrm{b}}$ & 0.1 \\
\hline SV3 & 8.6 & 0.2 & -0.2 & 0.2 & - & & -6.84 & 14.7 & 0.1 \\
\hline SV4 & 9.3 & 0.2 & 1.0 & 0.2 & - & & -6.83 & 15.4 & 0.1 \\
\hline SV5 & 9.4 & 0.3 & 0.2 & 0.2 & - & & -6.77 & 15.4 & 0.2 \\
\hline SV6 & 9.4 & 0.2 & -0.1 & 0.0 & - & & -6.78 & 15.2 & 0.1 \\
\hline SV7 & 9.5 & 0.4 & 0.2 & 0.3 & - & & -6.73 & $15.1^{\mathrm{a}}$ & 0.2 \\
\hline \multicolumn{10}{|c|}{ High Flow (Jan 2014) } \\
\hline SV1 & 11.5 & 0.1 & 7.0 & 0.6 & 15.1 & 0.1 & -6.50 & 18.6 & 0.1 \\
\hline SV2 & 12.0 & 0.1 & 7.4 & 0.1 & 18.2 & 0.4 & -6.60 & 19.0 & 0.2 \\
\hline SV3 & 4.7 & 0.1 & -0.8 & 0.6 & 33.7 & $*$ & -7.32 & $16.2^{\mathrm{c}}$ & 0.2 \\
\hline SV4 & 6.1 & 0.1 & 0.2 & 0.1 & - & & -7.34 & 16.8 & 0.1 \\
\hline SV5 & 8.9 & 0.1 & 2.1 & 0.2 & 20.2 & $*$ & -6.82 & 17.5 & 0.1 \\
\hline SV6 & 8.6 & 0.1 & 2.9 & 0.2 & 21.4 & $*$ & -6.90 & 17.7 & 0.2 \\
\hline SV7 & 8.6 & 0.1 & 3.2 & 0.3 & 19.2 & $*$ & -6.87 & 17.6 & 0.1 \\
\hline
\end{tabular}


Table 3. Measured temperature, $\delta^{18} \mathrm{O}_{\mathrm{PO} 4}$ and $\delta^{18} \mathrm{O}_{\mathrm{H} 2 \mathrm{O}}$ for water samples collected under low and high flow events on the River Beult; and the theoretical equilibrium $\delta^{18} \mathrm{O}_{\mathrm{PO} 4}$ calculated using Equation 3.

\begin{tabular}{lccccc}
\hline & $\begin{array}{c}\text { Measured } \\
\delta^{18} \mathrm{O}_{\mathrm{PO} 4}(\%)\end{array}$ & $\begin{array}{c}\text { Measured } \\
\delta^{18} \mathrm{O}_{\mathrm{H} 2 \mathrm{O}}(\%)\end{array}$ & $\begin{array}{c}\text { Measured } \\
\text { temperature } \\
\left({ }^{\circ} \mathrm{C}\right)\end{array}$ & $\begin{array}{c}\text { Theoretical } \\
\text { equilibrium } \\
\delta^{18} \mathrm{O}_{\mathrm{PO} 4}(\%)\end{array}$ & $\begin{array}{c}\text { Difference } \\
\text { (measured- } \\
\text { theoretical) } \\
\delta^{18} \mathrm{O}_{\mathrm{PO} 4}(\%)\end{array}$ \\
\hline Low flow (Sep 2013) & & & & \\
SV1 & 16.7 & -6.08 & 21.0 & 16.6 & 0.1 \\
SV2 & 16.6 & -5.22 & 17.2 & 18.1 & -1.5 \\
SV3 & 14.7 & -6.84 & 20.3 & 15.8 & -1.1 \\
SV4 & 15.4 & -6.83 & 18.6 & 16.2 & -0.8 \\
SV5 & 15.4 & -6.77 & 18.3 & 16.3 & -0.9 \\
SV6 & 15.2 & -6.78 & 18.4 & 16.3 & -1.1 \\
SV7 & 15.1 & -6.73 & 18.8 & 16.3 & -1.2 \\
\hline High flow (Jan & $2014)$ & & & & \\
SV1 & 18.6 & -6.50 & 7.4 & 18.5 & 0.1 \\
SV2 & 19.0 & -6.60 & 7.1 & 18.5 & -1.1 \\
SV3 & 16.2 & -7.32 & 9.6 & 17.3 & -0.4 \\
SV4 & 16.8 & -7.34 & 9.8 & 17.2 & -0.7 \\
SV5 & 17.5 & -6.82 & 7.3 & 18.2 & -0.5 \\
SV6 & 17.7 & -6.90 & 7.4 & 18.2 & -0.7 \\
SV7 & 17.6 & -6.87 & 6.8 & 18.3 & \\
\hline
\end{tabular}




\section{Sutton Valence}

spring source

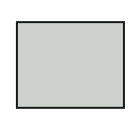

Poultry and soft fruit farm

1
Medway catchment

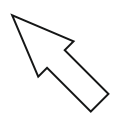

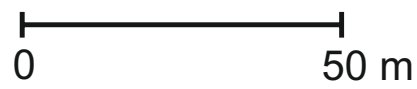

Sutton Valence WWTW

Small pond

Livestock farm
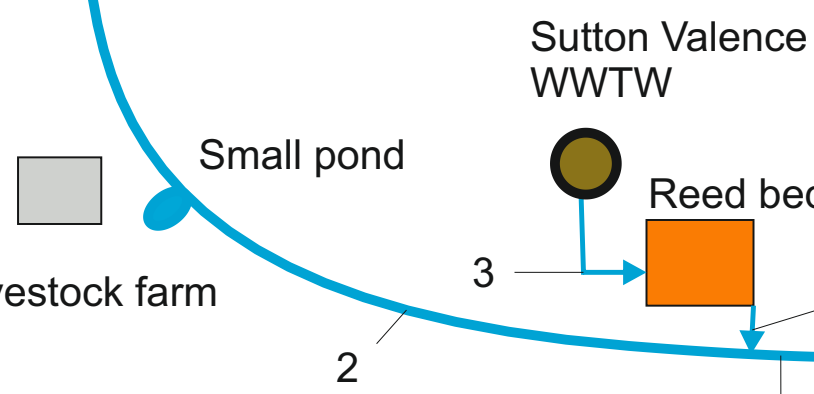

2

Figure 1. Location of the Beult catchment in England, UK (a) and schematic map of sample locations along a section of the river (b) 


\section{Field filtration}

0.45 micron
DAX-8 resin

water sample
Pump 5-10 L Dowex1X8-200

$4 \mathrm{~mL} / \mathrm{min} \quad$ Anion resin

Elute $(0.3 \mathrm{M} \mathrm{KCl})$

$2 \mathrm{~mL} / \mathrm{min}$

$0-100 \mathrm{~mL}$ fraction

collected

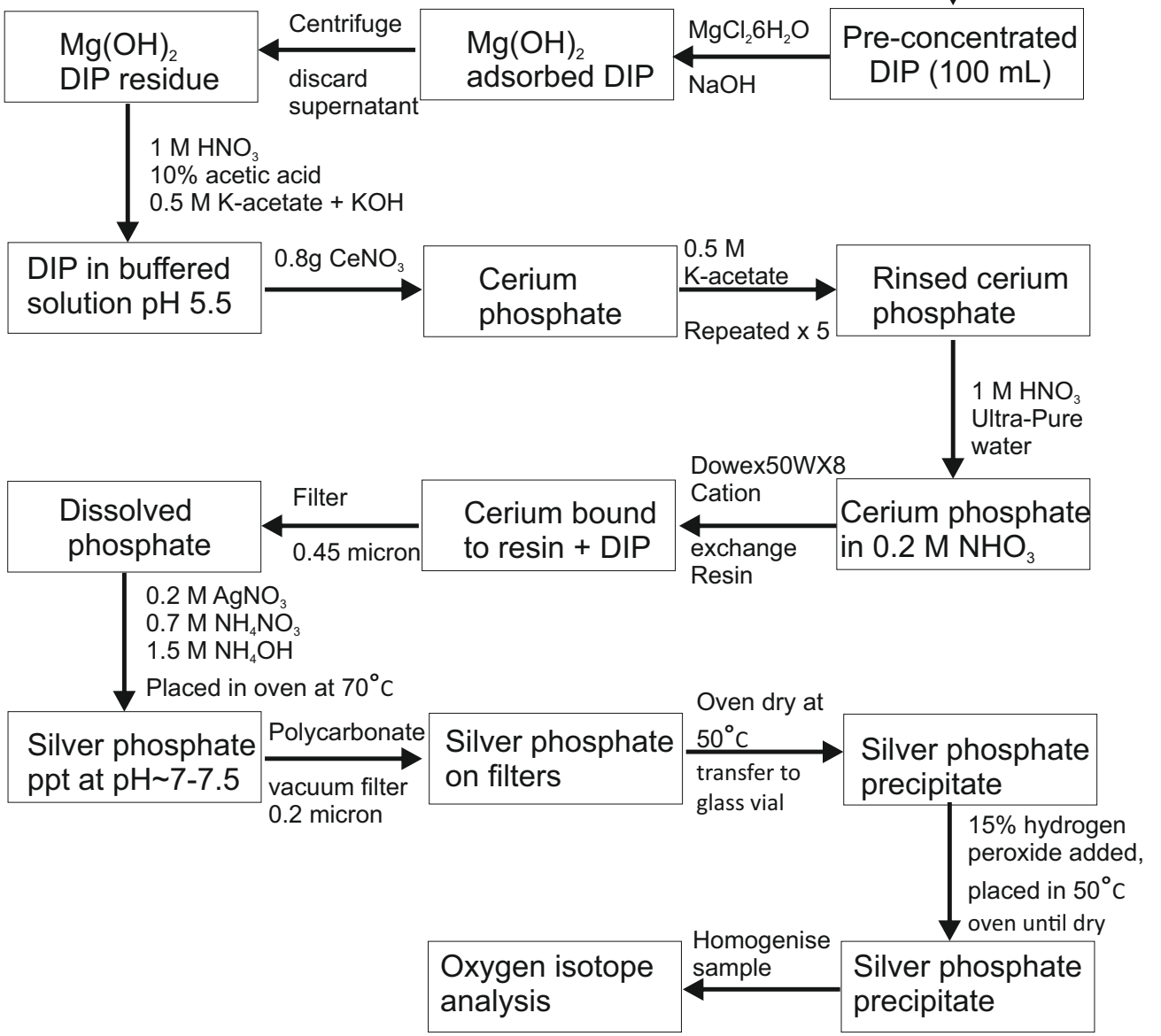

Figure 2. Schematic of the modified McLaughlin et al. (2004) protocol used to process water samples for $\delta^{18} \mathrm{O}_{\mathrm{PO} 4}$ analysis. 

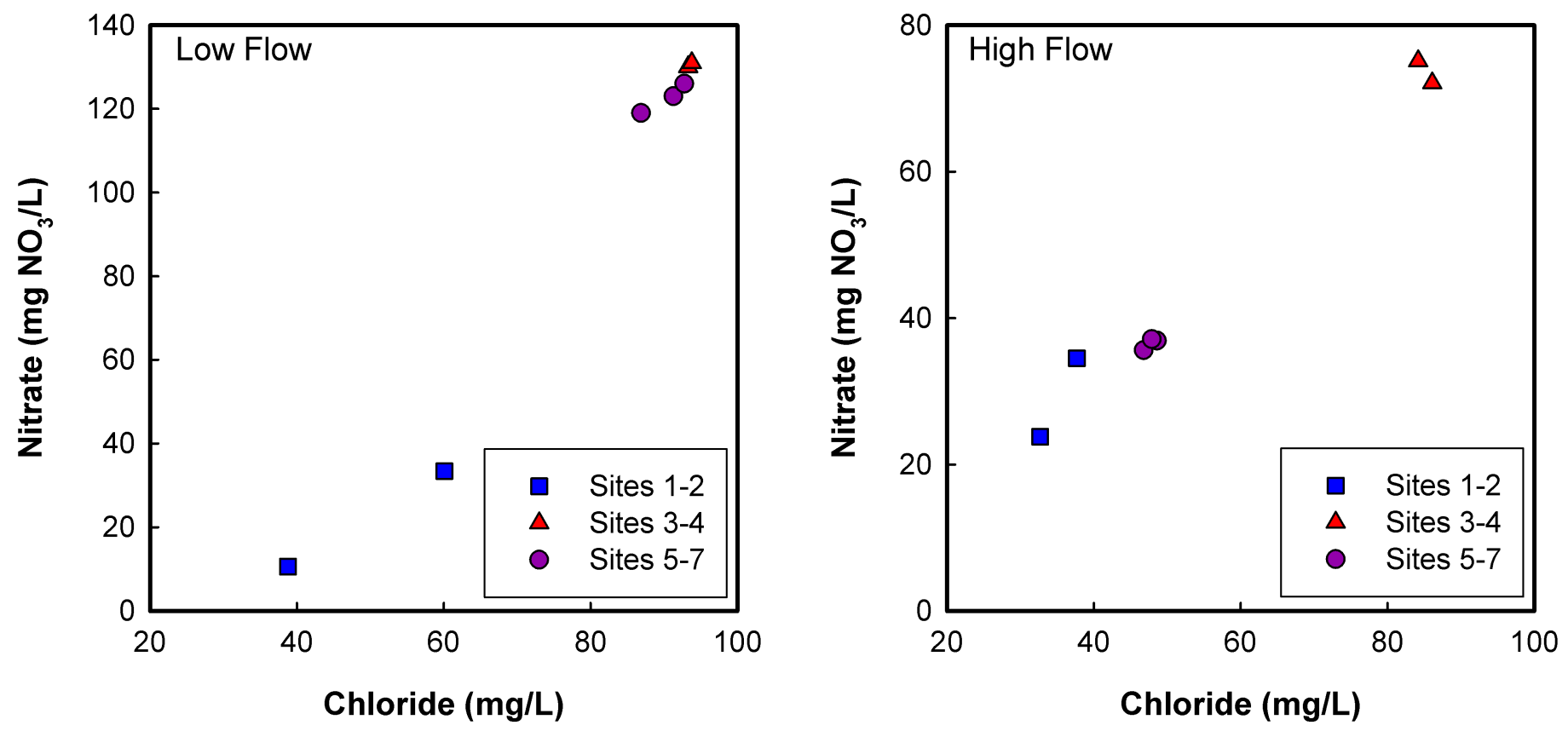

Figure 3. Nitrate concentration against chloride concentration for low and high flow sampling events. 

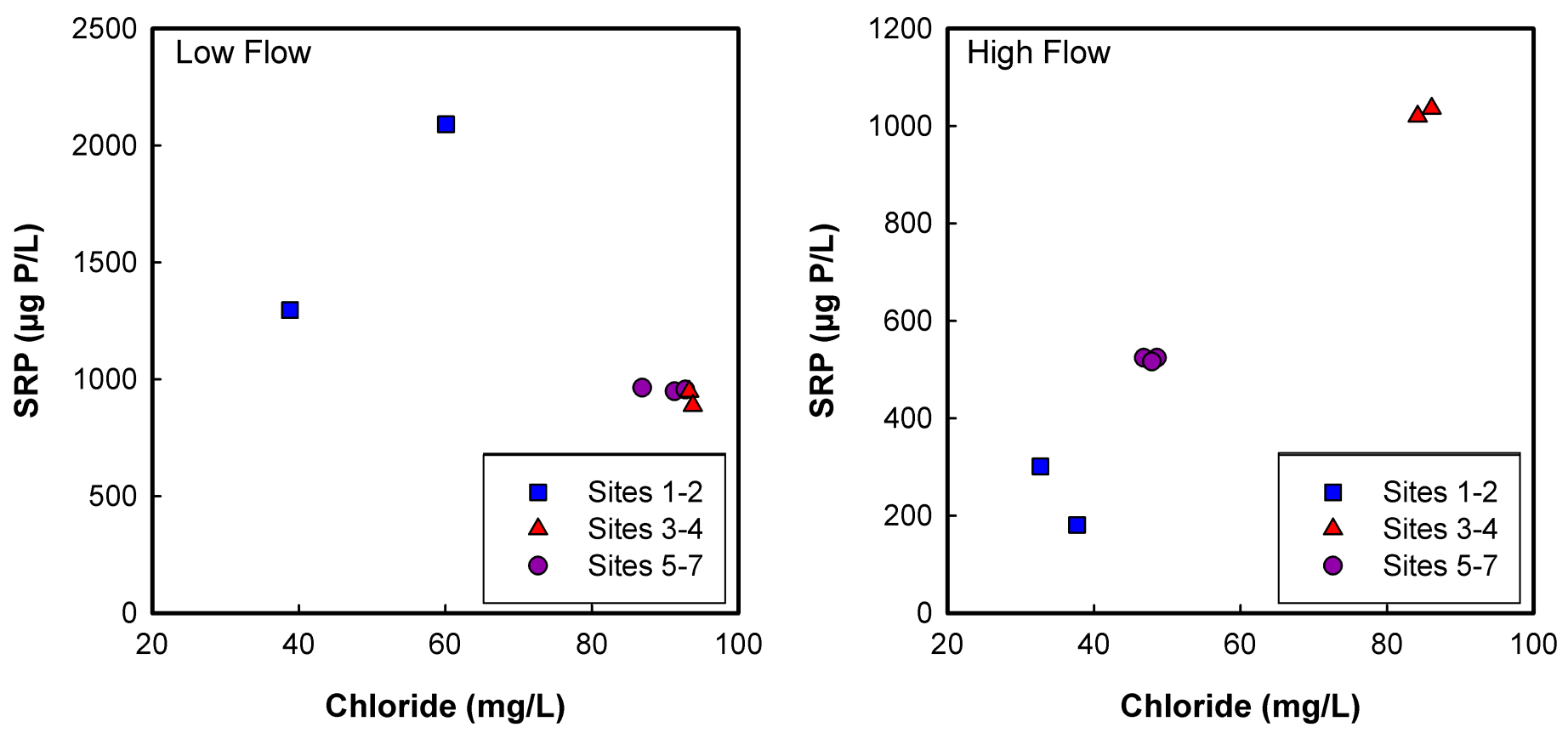

Figure 4. Soluble reactive phosphorus (SRP) concentration against chloride concentration for low and high flow sampling events (note change in scale of SRP concentration between low and flows). 

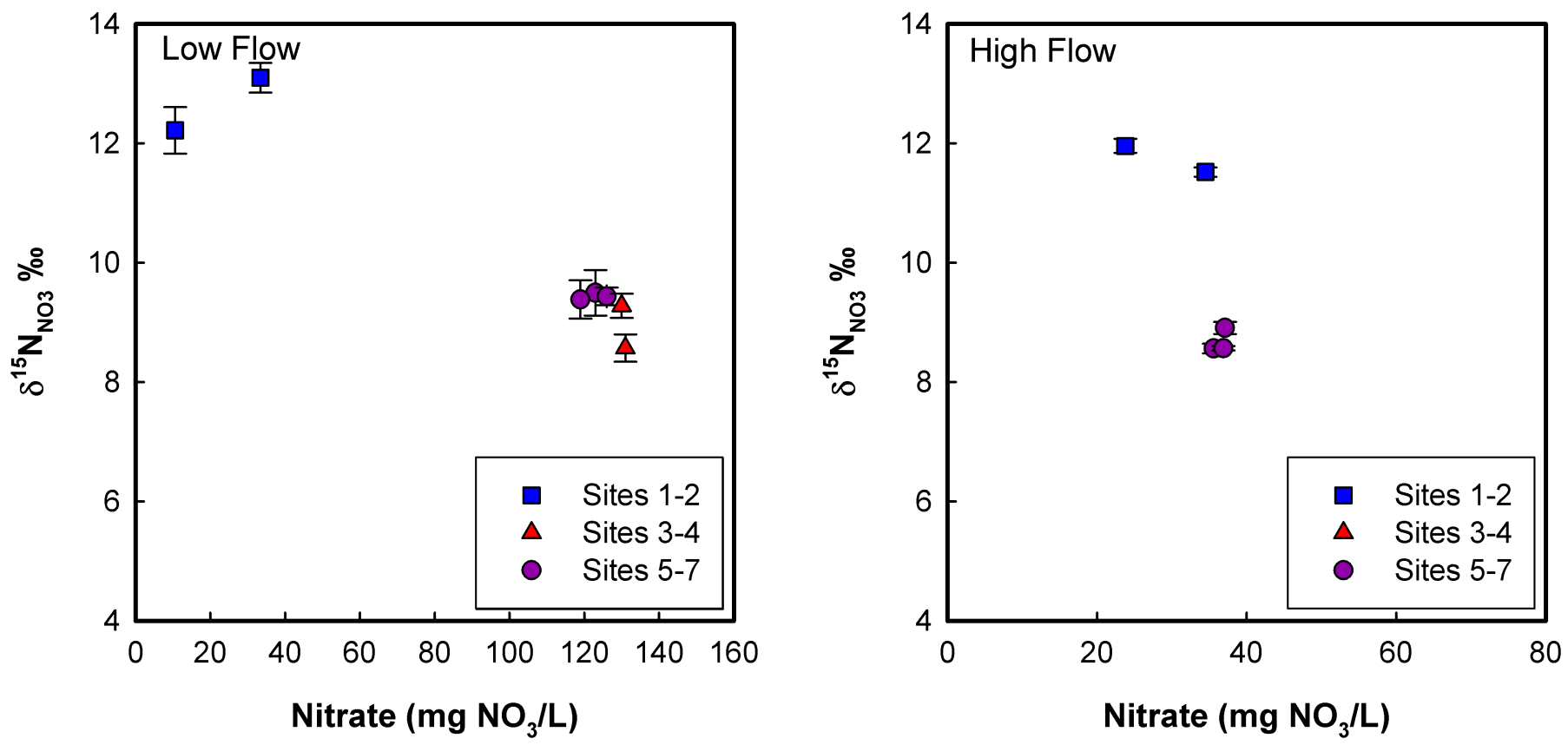

Figure 5. Nitrate-nitrogen isotope composition ( $\delta^{15} \mathrm{~N}_{\mathrm{NO} 3}$ ) composition against nitrate concentration for high and low flow sampling events. Vertical bars show standard deviation on $\delta^{15} \mathrm{~N}_{\mathrm{NO} 3}$ (note change in scale for nitrate concentration between high and low flow events). 

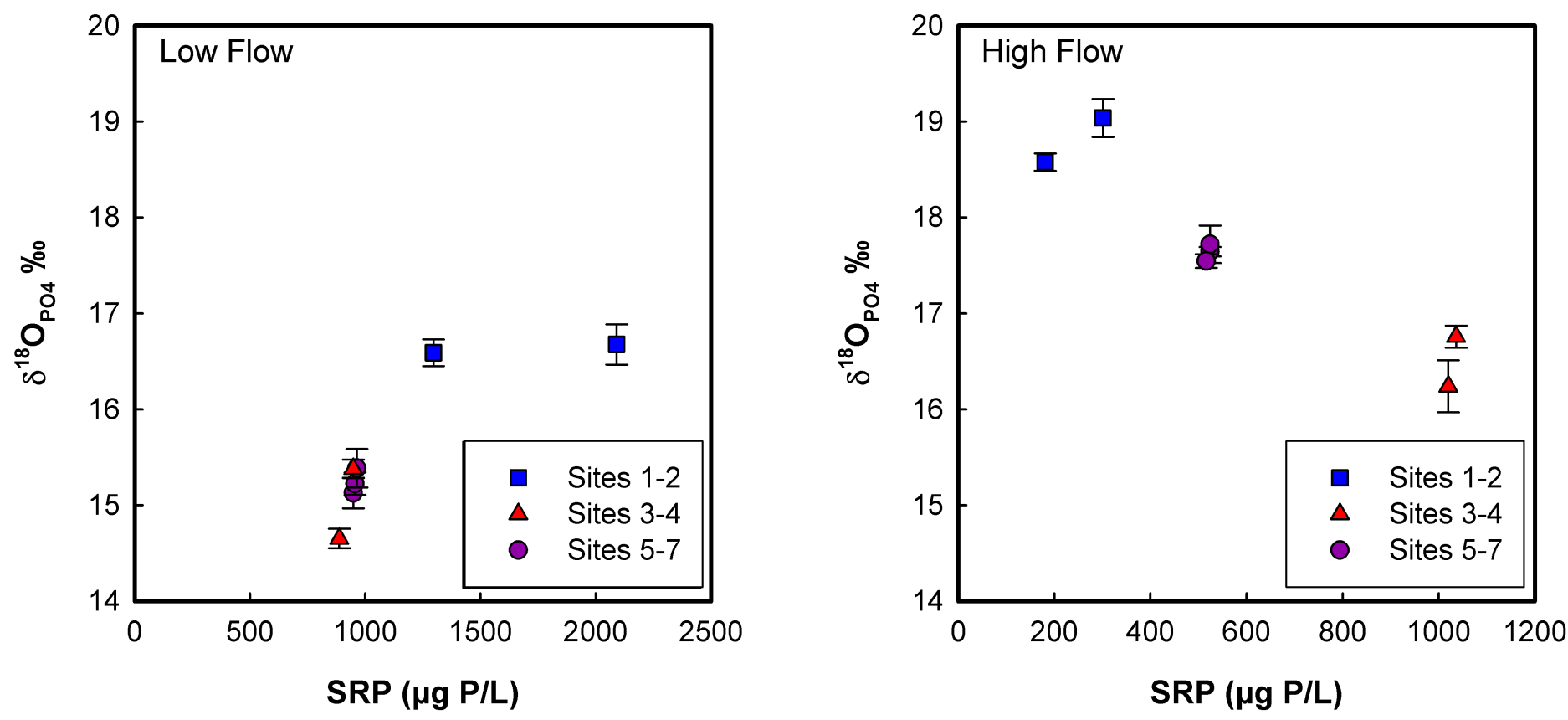

Figure 6. Stable phosphate oxygen composition $\left(\delta^{18} \mathrm{O}_{\mathrm{PO} 4}\right)$ composition against soluble reactive phosphorus (SRP) concentration for low and high flow sampling events. Vertical bars show standard deviation on $\delta^{18} \mathrm{O}_{\mathrm{PO} 4}$ (note change in scale for SRP concentration between low and high flow). 


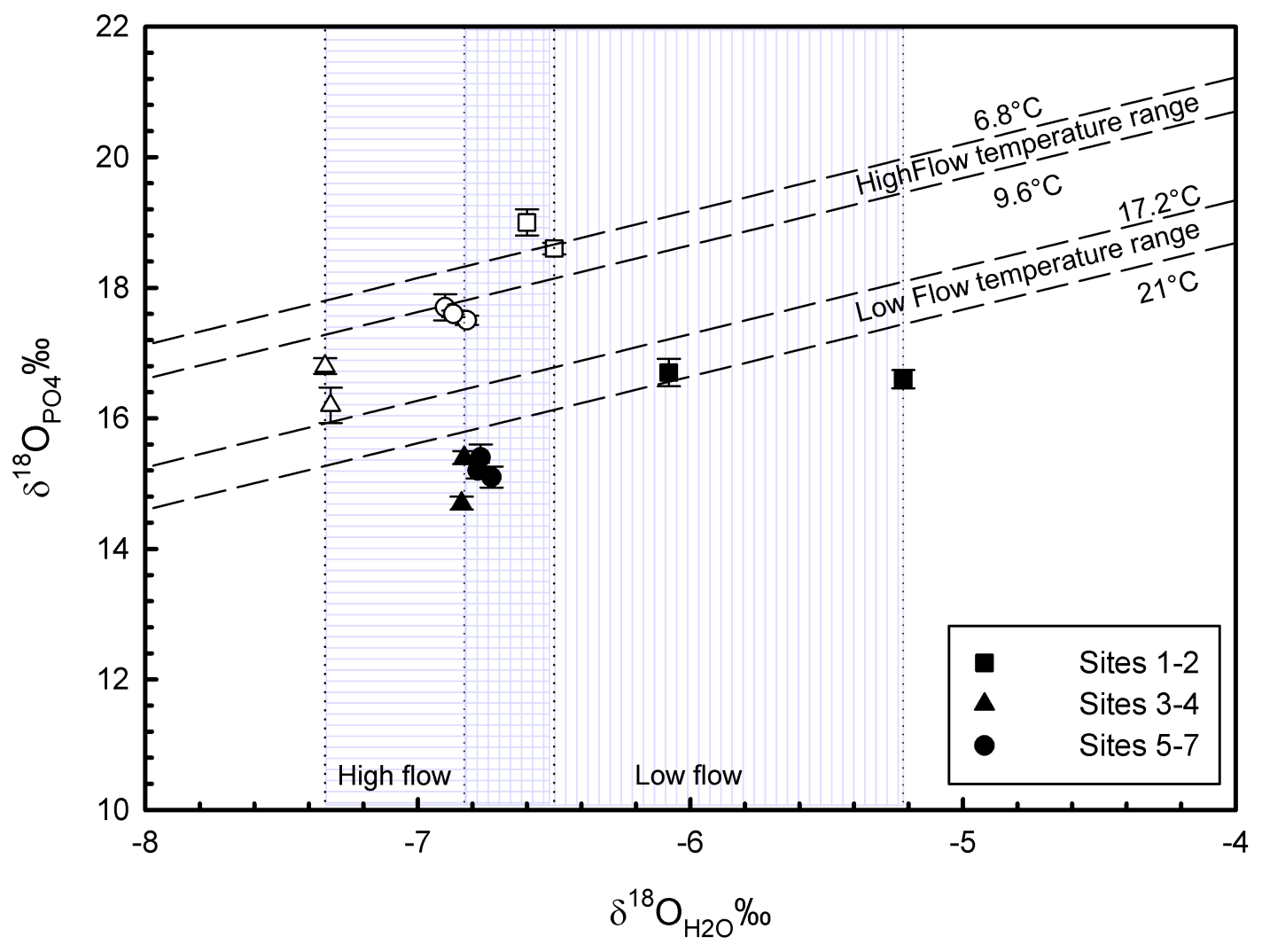

Figure 7. A comparison of $\delta^{18} \mathrm{O}_{\mathrm{PO} 4}$ and $\delta^{18} \mathrm{O}_{\mathrm{H} 2 \mathrm{O}}$ for samples collected in low flow (filled symbols) and high flow (open symbols). Vertical and horizontal hashed areas represent range of measured $\delta^{18} \mathrm{O}_{\mathrm{H} 2 \mathrm{O}}$ during low and high flows respectively. Diagonal dashed lines represent the $\delta^{18} \mathrm{O}_{\mathrm{PO} 4}$ equilibrium values for ambient water for the range of temperatures at low and high flows calculated using the equation of Chang and Blake (2015). 